\title{
Assessing the vulnerability of blanket peat to climate change using an ensemble of statistical bioclimatic envelope models
}

\author{
J. M. Clark ${ }^{1,2,10, *}$, A. V. Gallego-Sala ${ }^{3,11}$, T. E. H. Allott ${ }^{4}$, S. J. Chapman ${ }^{5}$, T. Farewell ${ }^{6}$, \\ C. Freeman ${ }^{1}$, J. I. House ${ }^{3}$, H. G. Orr ${ }^{7}$, I. C. Prentice ${ }^{1,3,8}$, P. Smith ${ }^{8,9}$ \\ ${ }^{1}$ Wolfson Carbon Capture Laboratory, School of Biological Sciences, Bangor University, Deiniol Road, Bangor, \\ Gwynedd LL57 2UW, UK \\ ${ }^{2}$ Grantham Institute for Climate Change Fellow, Civil and Environmental Engineering, Imperial College London, \\ Skempton Building, South Kensington, London SW7 2AZ, UK \\ ${ }^{3}$ QUEST, Department of Earth Sciences, University of Bristol, Wills Memorial Building, Queens Road, Bristol BS8 1RJ, UK \\ ${ }^{4}$ School of Environment and Development, University of Manchester, Oxford Road, Manchester M13 9PL, UK \\ ${ }^{5}$ Macaulay Land Use Research Institute, Craigiebuckler, Aberdeen AB15 8QH, UK \\ ${ }^{6}$ National Soils Research Institute, Cranfield University, College Road, Cranfield, Bedfordshire MK43 0AL, UK \\ ${ }^{7}$ Research and Innovation (Climate Change), Environment Agency, Environment Centre Wales, Deiniol Road, Bangor LL57 2UW, UK \\ ${ }^{8}$ Grantham Institute for Climate Change, Division of Life Sciences, Imperial College London, Silwood Park, Ascot, Berkshire SL5 7PY, UK \\ ${ }^{9}$ Institute of Biological and Environmental Sciences, School of Biological Sciences, Aberdeen University, 23 St Machar Drive, \\ Aberdeen AB24 3UU, UK \\ ${ }^{10}$ Present address: Walker Institute for Climate Systems Research and Soils Research Centre, Geography and Environmental \\ Science, School of Human and Environmental Sciences, University of Reading, Whiteknights, PO Box 233, Reading RG6 6DW, UK \\ ${ }^{11}$ Present address: Department of Earth and Ecosystem Sciences, Division of Physical Geography and Ecosystems Analysis, \\ University of Lund, Sölvegatan 12, 22362 Lund, Sweden
}

\begin{abstract}
We assessed the vulnerability of blanket peat to climate change in Great Britain using an ensemble of 8 bioclimatic envelope models. We used 4 published models that ranged from simple threshold models, based on total annual precipitation, to Generalised Linear Models (GLMs, based on mean annual temperature). In addition, 4 new models were developed which included measures of water deficit as threshold, classification tree, GLM and generalised additive models (GAM). Models that included measures of both hydrological conditions and maximum temperature provided a better fit to the mapped peat area than models based on hydrological variables alone. Under UKCIP02 projections for high (A1F1) and low (B1) greenhouse gas emission scenarios, 7 out of the 8 models showed a decline in the bioclimatic space associated with blanket peat. Eastern regions (Northumbria, North York Moors, Orkney) were shown to be more vulnerable than higher-altitude, western areas (Highlands, Western Isles and Argyle, Bute and The Trossachs). These results suggest a long-term decline in the distribution of actively growing blanket peat, especially under the high emissions scenario, although it is emphasised that existing peatlands may well persist for decades under a changing climate. Observational data from long-term monitoring and manipulation experiments in combination with process-based models are required to explore the nature and magnitude of climate change impacts on these vulnerable areas more fully.
\end{abstract}

KEY WORDS: Climate change $\cdot$ Peat $\cdot$ Bioclimatic envelope model $\cdot$ Great Britain $\cdot$ Uplands

\section{INTRODUCTION}

Blanket peat is the main peat type in Great Britain (GB, comprising England, Scotland and Wales), accounting for $92 \%$ of the total peatland area covering around
$23300 \mathrm{~km}^{2}(10 \%$ of GB land area), and is located almost exclusively in the uplands (see Fig. 1a). It is the single largest terrestrial carbon store in GB, accounting for ca. $50 \%$ of the total carbon stock (Milne \& Brown 1997). However, many of these areas have been 
degraded due to drainage, air pollution, rotational burning and wildfires, plantation forestry and overgrazing (Ramchunder et al. 2009). Restoration efforts are underway to block drains (Armstrong et al. 2009), re-vegetate areas of bare peat (Evans et al. 2004), change fire management (Davies et al. 2008) and reduce air pollution (RoTAP in press). Given the close relationship between peat formation and cool and wet climatic conditions, it is likely that future climate change will place additional pressure on these systems, particularly in degraded areas that are already subject to stress. However, it is currently unclear how vulnerable upland blanket peat across the various regions of GB will be to climate change. Understanding the climatic vulnerability of these issues will help prioritise and potentially 'climate-proof' blanket peat management and restoration work by informing policy debates about future protection and management of these areas and the services these ecosystems deliver.

Ombrotrophic peatlands tend to be found in wet and humid areas with no sustained dry periods (Moore \& Bellamy 1973). Organic matter accumulates in peat because of low decomposition rates (due to waterlogging and anoxia) rather than high plant productivity (Clymo 1984, Malmer 1992). Blanket peat vegetation is adapted to these saturated conditions, and is highly sensitive to changes in water availability (Bragg \& Tallis 1999). In these ombrotrophic systems, high water tables are maintained by precipitation and poor drainage due to impermeable underlying deposits (Taylor 1983). The reliance on precipitation makes blanket peat highly sensitive to climate changes that affect the net water balance (precipitation - potential evapotranspiration), as this alters the balance between decomposition and primary production (Heathwaite 1993).

Bioclimatic envelope models (BCEM) have been used to map the current and possible future distribution of various types of peatlands (Gignac et al. 1998, Fronzek et al. 2006, Parviainen \& Luoto 2007). Envelope models are static statistical models used to define the 'environmental space' where a habitat or species is present (Guisan \& Zimmermann 2000). Most applications are for species, with only a few considering landforms and habitats (e.g. Parviainen \& Luoto 2007). BCEMs can usefully inform policy development provided their limitations are understood (Heikkinen et al. 2006, Walmsley et al. 2007). These limitations relate to the static and empirical representation of relationships between habitat/species presence and explanatory variables which cannot account for possible dynamic feedbacks (Pearson \& Dawson 2003, Heikkinen et al. 2006). In spite of these limitations, BCEMs can provide a valuable first approximation of climate change impacts at broad geographic scales where climate is the pri- mary constraint on the distribution (Pearson \& Dawson 2003, Heikkinen et al. 2006, Ellis et al. 2007).

Within the climate space associated with boreal peatlands, blanket peat tends to form under the warmest and wettest conditions (Wieder \& Vitt 2006), where precipitation is around 3 times greater than potential evaporation (Pearsall 1965). Globally, these areas typically occur in mid to high latitudes on the ocean fringes where precipitation is high and mean annual temperature range is low (Lindsay et al. 1988). Climatic variables that have been used to determine blanket peat bioclimatic space include temperature, growing degree days, precipitation and water balance (precipitation potential evaporation) (see Table 1). Precipitation has been shown to be more important than temperature in explaining blanket bog distribution in Fennoscandia (Parviainen \& Luoto 2007), although in GB the distribution of precipitation measured in terms of the number of days with rainfall was considered to be more important than the total precipitation in explaining blanket peat distribution (Tansley 1939, Goode \& Ratcliffe 1977, Lindsay et al. 1988). This is most likely because the number of rain days has been linked with Sphagnum moss growth and primary production (Backeus 1988, Lindsay 1995). Mean temperature has also been used as an explanatory variable for blanket peat in GB in the absence of maximum temperature data (Hossell et al. 2000). Maximum temperature is thought to be the main factor limiting the distribution of upland montane plant species (Rodwell et al. 1992) as invasion of faster growing species becomes more likely with warmer temperatures (Hossell et al. 2000).

Climate projections for the 21st century for GB suggest an overall increase in temperatures and change in the distribution of rainfall with warmer, wetter winters and warmer, drier summers (Hulme et al. 2002, Jenkins et al. 2009). Given that wet and cool conditions are associated with blanket peat, these projected changes could affect the species composition and the balance between carbon accumulation and decomposition. While the potential risks to blanket peat stability in a changing climate are known qualitatively (e.g. potential for shift from net carbon sink to source as decomposition increases under warmer and drier conditions), the degree to which these changes may place additional stress on blanket peat systems is unclear. In particular, the relative climatic vulnerability between regions across GB is unknown. Previous work within GB has focused on temperature alone as a key BCEM model variable using UKCIP98 scenarios (Hossell et al. 2000), although precipitation and changes in the water balance have been shown to be a key explanatory variables of blanket peat elsewhere (Parviainen \& Luoto 2007). Therefore, the objectives of this study were to (1) develop new suitable BCEMs for British blanket 
peat that incorporate measures of the water balance; (2) compare the performance of the new BCEMs with previously published models; (3) identify regions within GB that are likely to be the most vulnerable to climate change; and (4) apply an ensemble of these new and existing BCEMs, together with recent climate projections, to examine future changes in the 'climate space' associated with blanket peat.

\section{METHODS}

\subsection{Derived peat map}

No unified soil or blanket peat map was available for $\mathrm{GB}$; therefore a derived blanket map was produced by combining the mapped area of blanket peat from the Digital National Soil Map for England and Wales (NATMAPvector, 1:250 000) and Scotland (National Soils Map, NSM, 1:250 000), which have different classification systems. In England and Wales, peat soils meet both of the following criteria: (1) either, $>40 \mathrm{~cm}$ of organic material is found within the upper $80 \mathrm{~cm}$ of the soil profile, or $>30 \mathrm{~cm}$ of organic material rests directly on bedrock or skeletal material; and (2) there are no superficial nonhumose mineral horizons with a colour value of $\geq 4$ extending below $30 \mathrm{~cm}$ depth (Clayden \& Hollis 1984). Blanket peat was mapped under 3 soil associations: Winter Hill (1011b), Crowdy 1 (1013a) and Crowdy 2 (1013b), belonging to the raw peat soils group (10.1) (Avery 1980). In Scotland, peat is classified as an organic deposit ( $>60 \%$ organic matter) with a depth $>50 \mathrm{~cm}$. The soil map unit 'Blanket Peat' was mapped into 4 classifications: Blanket Peat, Deep Blanket Peat, Eroded Blanket Peat and Eroded Deep Blanket Peat. There are additional soil map units where peat is a major component that has developed in patches with other organic soils over glacial moraine in 'organic soil complexes' (Chapman et al. 2009). These areas of semi-confined peat were not included in our derived blanket peat map.

The National Soil Map for Scotland was published in 1982, combining detailed soil surveys carried out in the 1950s for lowland areas and 1970s for upland areas. Given that blanket peat is predominately in the uplands, the National Soil Map for Scotland best represents the mapped distribution in the 1970s. The National Soil Map for England and Wales was mapped between 1979 and 1982. The peat maps show the area of blanket peat extent at the time of field survey. While it is known that blanket peat in GB has been impacted by land use (e.g. forestry, drainage and cutting), the impact of this on the mapped distribution of blanket peat areas across the whole country is currently unknown. However, it is important to note that drained and afforested areas of peat where the organic layer is still of sufficient depth will have been mapped as peat. Therefore, work presented here shows BCEM models calibrated to the mapped distribution of blanket peat from the 1970s.

The mapped polygons of these soil associations and series were combined to produce a single blanket peat layer for GB. The polygons were then converted to a $5 \mathrm{~km}$ grid based on the presence (3110 cells) or absence (7765 cells) of blanket peat within each grid cell. A $5 \mathrm{~km}$ grid was chosen to match the resolution of the available climate data (Fig. 1a).

\subsection{Climate data}

\subsubsection{Observed data}

Monthly gridded climate data (5 km resolution) from the UK Met Office were used (www.metoffice.gov.uk). The gridded data were produced by interpolating long-term meteorological measurements using multiple regression models accounting for location and elevation in addition to other factors (Perry \& Hollis 2005). Datasets used in this paper were monthly mean of the minimum and maximum daily temperature $\left({ }^{\circ} \mathrm{C}\right)$, total precipitation $(\mathrm{mm})$, cloud cover (\%) and days with rainfall $>1 \mathrm{~mm}$ (d). Mean temperature was calculated as the mean of maximum and minimum temperature. Monthly data were averaged over the 1961-1990 baseline period.

\subsubsection{Climate projections}

Climate scenarios were available for GB from the UK Climate Impacts Programme (UKCIP, www.ukcip. org.uk) (Hulme et al. 2002). These scenarios were derived from the Hadley Centre Global Climate Model (HadCM3) for 4 global emission profiles (IPCC 2000): A1F1 (high emissions), A2 (medium-high emissions), B2 (medium-low emissions), B1 (low emissions). We used the high and low emissions scenarios. Changes in monthly mean climate values were available for the periods 2011-2040 (2020s), 2041-2070 (2050s) and 2071-2100 (2080s) at a $50 \mathrm{~km}$ scale. The projected change in climate variables at the $50 \mathrm{~km}$ scale were applied to the observed 1961-1990 $5 \mathrm{~km}$ baseline data. Projected changes used were for monthly change in maximum and minimum temperature $\left({ }^{\circ} \mathrm{C}\right)$, total precipitation (\%) and cloud cover (\%). No direct data were available for future raindays.

UKCIP02 was used, as the more recent UKCP09 scenarios were not available at the time the work was carried out. In general, UKCIP02 projections show a rise in average annual temperature of 1 to $5^{\circ} \mathrm{C}$, a decrease in summer precipitation by up to $50 \%$ and an 

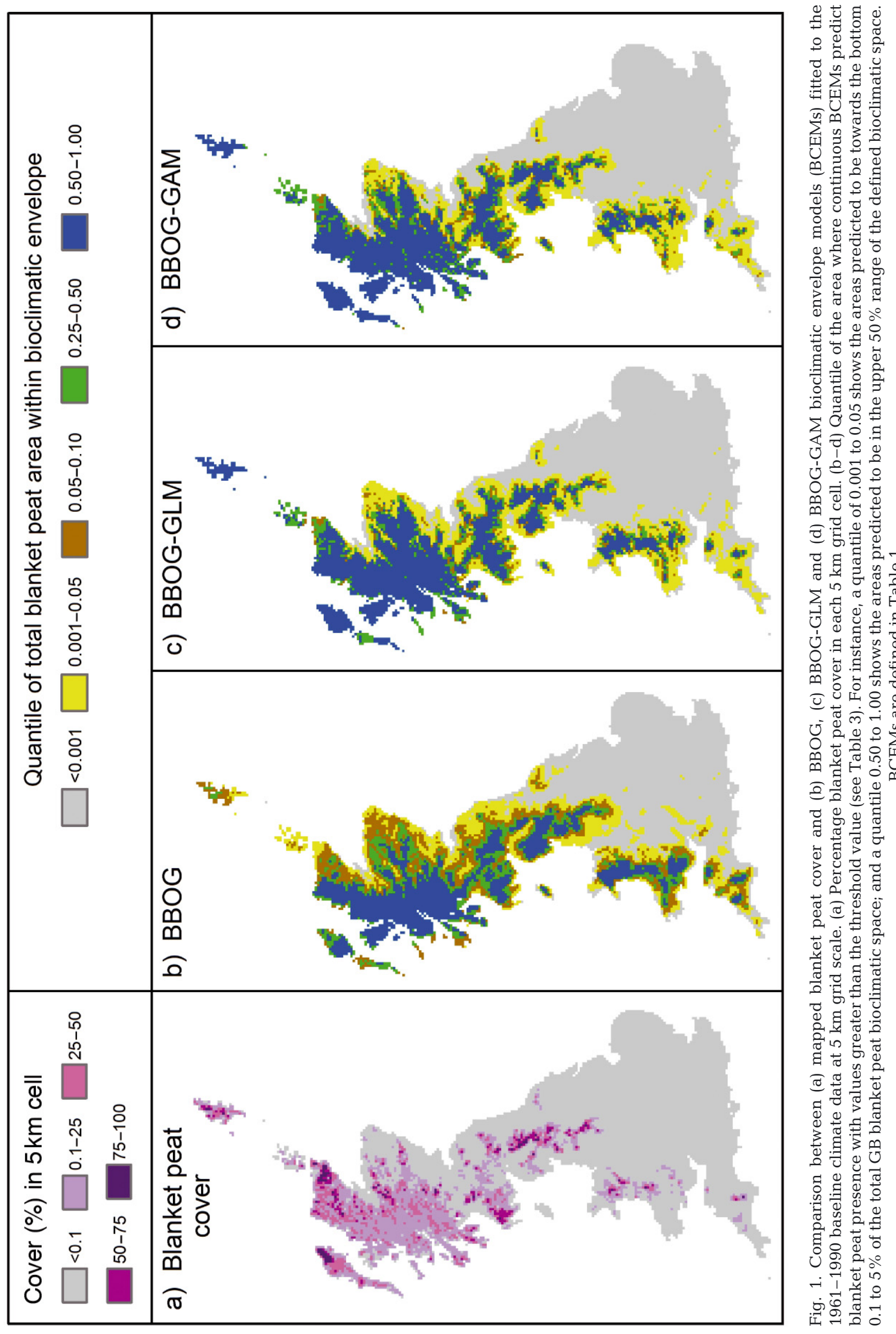
increase in winter precipitation by up to $30 \%$ by 2071-2100, relative to the 1961-1990 baseline, depending on region and emission scenario (Hulme et al. 2002). In UKCIP02, there is only one model output for each of the 4 different emissions scenarios. In comparison, UKCP09 projections are based on 10000 model outputs for 3 emission scenarios, and provide more complex probabilistic projections. Projected increases in mean winter and summer temperature across administrative regions from UKCP09 range from 0.9 to $8.1^{\circ} \mathrm{C}$, with $50 \%$ probability of an increase of 2.0 to $5.0^{\circ} \mathrm{C}$ for low to high emission scenarios. In terms of precipitation, projections show a $50 \%$ probability of a 9 to $35 \%$ decrease in mean summer precipitation and a $50 \%$ probability of an 11 to $30 \%$ increase in winter precipitation across each administrative region (Murphy et al. 2009). Hence the range of projections under UKCIP02 is similar in magnitude to the range of projections under UKCP09 with 50\% probability.

\subsubsection{Derived climate variables}

Potential evapotranspiration (PET): Estimates of PET were needed to estimate changes in the water balance. Many equations are available with differing data requirements. As the statistical envelope models developed were applied over a wide area, 3 models were chosen with minimal data requirements: the modified Thornthwaite (Thornthwaite 1948, Mather 1978), Priestley-Taylor (Priestley \& Taylor 1972) and Hargreaves (Hargreaves et al. 1985, Allen et al. 1998) equations (see Supplement 1, available at www.int-res. com/articles/suppl/c045p131_supp.pdf). Although the Penman-Montieth equation is regarded as the most physically-based model, it was not used due to the impossibility of specifying some of its parameters, including wind speed and conductances. Greater uncertainty with some of the projected climate variables needed for the Penman-Monteith model (e.g. wind speed) can result in unreliable forecasts of PET (Kay \& Davies 2008).

Modified Thornthwaite-Mather moisture index: The Thornthwaite-Mather moisture index (TMI) is a measure the annual balance between precipitation $(P)$ and PET (Thornthwaite \& Mather 1955, Willmott \& Feddema 1992):

$$
\mathrm{TMI}=\left\{\begin{array}{l}
P / \mathrm{PET}-1, P<\mathrm{PET} \\
1-\mathrm{PET} / P, P \geq \mathrm{PET}
\end{array}\right.
$$

PET was estimated using the modified Thornthwaite equation. The TMI presents values scaled between -1 (very dry) to 1 (very wet), providing a relative measure of the degree of wetness or aridity that would be hard to determine from the difference between the absolute values alone.
Annual accumulated monthly water deficit (AAMWD):

$$
\begin{aligned}
& \mathrm{AAMWD}=\sum_{m=1}^{12} \mathrm{MWD} \\
& \text { where } \mathrm{MWD}= \begin{cases}P-\mathrm{PET} & {[P<\mathrm{PET}]} \\
0 & {[P>\mathrm{PET}]}\end{cases}
\end{aligned}
$$

where MWD is the monthly water deficit $(P-\mathrm{PET})$ for month $m_{i} P$ is precipitation $\left(\mathrm{mm} \mathrm{mo}^{-1}\right)$; PET is potential evapotranspiration $\left(\mathrm{mm} \mathrm{mo}^{-1}\right)$. The AAMWD was calculated for each of the 3 evaporation models. The AAMWD takes into account seasonality in the balance between $P$ and PET, which is not considered in annual indices like TMI. Seasonality can be a better, and more appropriate, explanatory variable for bog distributions than annual indexes (Gignac et al. 2000). The approach is also consistent with previous methods used to analyse paleoecological reconstructions of water tables with respect to observed climate data and calculated total seasonal water deficit accumulated over a year (Charman 2007, Charman et al. 2009).

Continentality: Continentality was calculated as the difference between maximum and minimum monthly mean temperature (after Parviainen \& Luoto 2007). Minimal seasonal variation in temperature is associated with blanket bog distribution (Lindsay et al. 1988). This variable has also been found to be a good predictor of blanket peat areas amongst a peatland complex of other mire types (Parviainen \& Luoto 2007).

Accumulated temperature: Accumulated temperature is the annual sum of the monthly mean temperature multiplied by the number of days in each month (Gregory 1954). Although not the same as growing degree days, analysis showed a good correlation between these 2 variables (Clark et al. 2010, this Special), and the accumulated temperature is easier to calculate. Most notably, it provides a key physiological variable in terms of plant growth.

\subsection{Statistical envelope model ensemble}

\subsubsection{Published blanket peat BCEMs}

There are few published statistical blanket peat envelope models. Four models found in the literature were used here. Pearsall noted that blanket bog in GB tends to occur in areas of precipitation $>1250 \mathrm{~mm} \mathrm{yr}^{-1}$ (Pearsall 1950) and where precipitation is $>3$ times the annual potential evapotranspiration (Pearsall 1965). We have formalised these observations as simple threshold models (Table 1). Hossell et al. (2000) derived a model based on mean annual temperature (T) (Table 1), which was chosen in the absence of available data on maximum average temperature $\left(\mathrm{T}_{\max }\right)$. Lindsay et al. (1988) defined conditions associated with blanket bog 
Table 1. Statistical bioclimatic envelope models for blanket peat from published sources and derived in this paper. Models range from simple thresholds or 'rule of thumb' to classification tree (CLT), generalised linear models (GLM) and generalised additive models (GAM). P(BP): probability of blanket peat occurrence (presence $=1$, absence $=0$ ). All other variables defined in Table 2

\begin{tabular}{|c|c|c|c|}
\hline Abbreviation & Method & Model & Source \\
\hline P50 & Threshold & $\mathrm{P}(\mathrm{BP})=1$ if $P>1250 \mathrm{~mm} \mathrm{yr}^{-1}$ & Pearsall (1950) \\
\hline P65 & Threshold & $\mathrm{P}(\mathrm{BP})=1$ if $P>3(\mathrm{PET})$ & Pearsall (1965) \\
\hline H-GLM & GLM & $\mathrm{P}(\mathrm{BP})=\frac{\exp [21.64-2.6145 \mathrm{~T}]}{1+\exp [21.64-2.6145 \mathrm{~T}]}$ & Hossell et al. (2000) \\
\hline $\mathrm{L}$ & Threshold & $\begin{array}{c}\mathrm{P}(\mathrm{BP})=1 \text { if } P>1000 \mathrm{~mm} \mathrm{yr}^{-1} \\
\mathrm{~T}_{\mathrm{m}}<15^{\circ} \mathrm{C} \\
>160 \mathrm{RD}\end{array}$ & Lindsay et al. (1988) \\
\hline L-GLM & GLM & $\mathrm{P}(\mathrm{BP})=\frac{\exp \left(3.472-1.046 \mathrm{~T}_{\mathrm{m}}+0.001140 P+0.05379 \mathrm{RD}\right)}{1+\exp \left(3.472-1.046 \mathrm{~T}_{\mathrm{m}}+0.001140 P+0.05379 \mathrm{RD}\right)}$ & after Lindsay et al. (1988) \\
\hline L-GAM & GAM & $\begin{array}{l}\mathrm{P}(\mathrm{BP})=f_{1}\left(\mathrm{~T}_{\mathrm{m}}\right)+f_{2}(P)+f_{3}(\mathrm{RD}) \\
\text { where } f_{1}, f_{2} \text { and } f_{3} \text { are cubic smoothing splines with smoothing } \\
\text { parameters } 6.8,8.6 \text { and } 7.4 \text {, respectively }\end{array}$ & after Lindsay et al. (1988) \\
\hline LM & Threshold & $\begin{array}{c}\mathrm{P}(\mathrm{BP})=1 \text { if } P>1000 \mathrm{~mm} \mathrm{yr}^{-1} \\
\mathrm{~T}_{\mathrm{m}}<15^{\circ} \mathrm{C}\end{array}$ & after Lindsay et al. (1988) \\
\hline LM-GLM & GLM & $\mathrm{P}(\mathrm{BP})=\frac{\exp \left(16.12-1.512 \mathrm{~T}_{\mathrm{m}}+0.003452 P\right)}{1+\exp \left(16.12-1.512 \mathrm{~T}_{\mathrm{m}}+0.003452 P\right)}$ & after Lindsay et al. (1988) \\
\hline LM-GAM & GAM & $\begin{array}{l}\mathrm{P}(\mathrm{BP})=f_{4}\left(\mathrm{~T}_{\mathrm{m}}\right)+f_{5}(P) \\
\text { where } f_{4} \text { and } f_{5} \text { are cubic smoothing splines with smoothing } \\
\text { parameters } 6.4 \text { and 8.8, respectively }\end{array}$ & after Lindsay et al. (1988) \\
\hline BBOG & Threshold & $\mathrm{P}(\mathrm{BP})=1$ if $\mathrm{AAMWD}_{\mathrm{PT}}>-45.1 \mathrm{~mm} \mathrm{yr}^{-1}$ & Present study \\
\hline BBOG-TREE & CLT & $\begin{aligned} \mathrm{P}(\mathrm{BP})=1 \text { if } \mathrm{T}_{\max } & <17.4, \mathrm{TMI}>0.41 \\
\mathrm{~T}_{\max } & >17.4, \mathrm{AAMWD}_{\mathrm{PT}}<-28.6 \mathrm{~mm} \mathrm{yr}^{-1}\end{aligned}$ & Present study \\
\hline BBOG-GLM & GLM & $\mathrm{P}(\mathrm{BP})=\frac{\exp \left(13.51-1.341 \mathrm{~T}_{\mathrm{m}}+9.165 \mathrm{TMI}\right)}{1+\exp \left(13.51-1.341 \mathrm{~T}_{\mathrm{m}}+9.165 \mathrm{TMI}\right)}$ & Present study \\
\hline BBOG-GAM & GAM & $\begin{array}{l}\mathrm{P}(\mathrm{BP})=f_{6}\left(\mathrm{~T}_{\min }\right)+f_{7}(\mathrm{C})+f_{8}(\mathrm{TMI}) \\
\text { where } f_{6}, f_{7} \text { and } f_{8} \text { are cubic smoothing splines with smoothing } \\
\text { parameters } 8.4,6.0 \text { and } 6.1 \text {, respectively }\end{array}$ & Present study \\
\hline
\end{tabular}

distribution as occurring in areas with precipitation

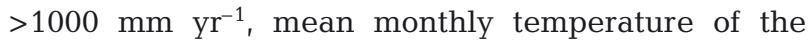
warmest month $\left(\mathrm{T}_{\mathrm{m}}\right)$ less than $15^{\circ} \mathrm{C}$ and more than 160 days per year with rainfall. As future raindays were not readily available from some climate model projections, the Lindsay model was modified by removing the raindays term. The effect of removing raindays was compared with the original threshold model using the observed baseline data (1961-1990).

\subsubsection{Derived blanket peat BCEMs}

Measured and derived climatic variables thought to be associated with blanket peat development were considered in statistical analysis between baseline climate data (1961-1990) and the presence/absence blanket peat map for GB. We adopted a similar approach to Fronzek et al. (2006) and Parviainen and Luoto (2007). The blanket peat and climate data were split into calibration and validation data sets, with $70 \%$ of the presence and absence data randomly selected for model calibration and the remaining data kept for evaluation. Fifteen climate variables used were (see also Table 2): mean annual temperature (T), maximum of the mean monthly daily maximum temperature (referred to as maximum temperature) $\left(\mathrm{T}_{\max }\right)$, minimum of the mean monthly daily minimum temperature (referred to as minimum temperature) $\left(\mathrm{T}_{\min }\right)$, maximum $\mathrm{T}_{\mathrm{m}}$ (as used by Lindsay et al. 1988), accumulated temperature $\left(\mathrm{T}_{\mathrm{ac}}\right)$, continentality $(\mathrm{C})$, total annual precipitation (P), total annual PET (estimated after Thornthwaite $\left(\mathrm{PET}_{\mathrm{Th}}\right)$, Preistley-Taylor $\left(\mathrm{PET}_{\mathrm{PT}}\right)$ and Hargreaves $\left(\mathrm{PET}_{\mathrm{H}}\right)$ ), and AAMWD (estimated using each of the 3 evaporation methods $\left(\mathrm{AAMWD}_{\mathrm{Th}}, \mathrm{AAMWD}_{\mathrm{PT}}\right.$, $\mathrm{AAMWD}_{\mathrm{H}}$ )). Raindays were included for comparative analysis in initial stages, although were removed from final models (see Section 2.3.2).

A set of 4 statistical models for British blanket bog (BBOG ensemble) were derived. A range of statistical models commonly used for the development of habitat models were used (Guisan \& Zimmermann 2000): simple 
threshold, regression and classification tree (TREE), logistic regression with logit link function (generalized linear model, GLM) and generalized additive model (GAM). GAM analysis was carried out using cubic regression smoothing splines (Zuur et al. 2009). A simple threshold model (BBOG) was chosen by selecting the most appropriate single variable that best matched the mapped blanket peat area. Thresholds were set at the 5th or 95th percentile for the climate variable covering cells containing blanket peat used for model calibration to ensure that $95 \%$ of the current mapped blanket peat area was included within the model. The choice of climate variable was based on the minimum area falling outside the mapped peat area (i.e. the ability of the climate variable to closely define the niche space) and expert opinion about the relevance of the climatic variable with respect to understanding how it influences peat formation. For the classification/regression tree (BBOG-TREE), logistic regression (BBOG-GLM) and GAM (BBOG-GAM), a 2 stage search procedure was carried out. (1) Significant variables $(p<0.05)$ were selected automatically within the regression tree and by step-wise backward selection within the GLM and GAM from all the climate variables used in the analysis. Expert opinion was then used to create meaningful combinations of the significant climatic variables, taking care to ensure models were not over fitted by including highly correlated variables. Each model combination was evaluated, and model selection was based on the minimal number of variables needed to explain the variance in the data (i.e. the most parsimonious model), the lowest residual deviance, AIC (Akaike's Information Criterion) and whether a change in variables was significant according to ANOVA between model fits (using a chi-squared distribution). To further compare the effect of different statistical models used, the simple threshold models were compared with GLM and GAM models fitted to the same climate variables used for both the original and modified Lindsay threshold models.

\subsection{Data analysis}

Assessment of the bioclimatic model fit was carried out on the verification data set. Model sensi- tivity, accuracy and Kappa statistic (Cohen 1960) were calculated for all models based on presence/absence of blanket peat defined from a critical threshold. For threshold and classification tree models, these critical thresholds were defined as part of the model structure. For GLM and GAM models, the critical predicted probability $\mathrm{P}(\mathrm{BP})$ was selected as the value covering $95 \%$ of the blanket peat area in the verification data set. Sensitivity was defined as the total number of recorded presences correctly predicted as a fraction of the total number of presences recorded in the data (Pearce \& Ferrier 2000). Accuracy was defined as the number of correctly identified presence and absence recorded in the whole data set (Pearce \& Ferrier 2000). The Kappa statistic was used because it provides a more meaningful measure of classification accuracy, as it compares actual classification with the classification that may have occurred by chance (Monserud \& Leemans 1992).

For GLM and GAM models, the square of the residual deviance $\left(\mathrm{D}^{2}\right)$ and the AUC (area under a relative operating characteristic curve) were also used. $\mathrm{D}^{2}$ is a measure of deviation of residual from the fitted model to the null model, and is analogous to $\mathrm{R}^{2}$ in normal regression models (Guisan \& Zimmermann 2000). Unlike Kappa, the AUC provides a threshold independent estimate of model performance (Pearce \& Ferrier 2000).

Table 2. Threshold for each climate variable required to cover $95 \%$ of the mapped blanket peat area in the calibration data set from baseline 1961-90 climate data. Area without blanket peat cover is shown. 5 th or 95 th percentile was selected. ${ }^{\circ} \mathrm{D}$ : degree-days

\begin{tabular}{|c|c|c|c|c|}
\hline Variable & Abbreviation & Units & $\begin{array}{l}95 \% \\
\text { threshold }\end{array}$ & $\begin{array}{c}\text { No blanket } \\
\text { peat }(\%)\end{array}$ \\
\hline Maximum temperature & $\mathrm{T}_{\max }$ & ${ }^{\circ} \mathrm{C}$ & 17.91 & 34.6 \\
\hline $\begin{array}{l}\text { Maximum monthly mean } \\
\text { temperature }\end{array}$ & $\mathrm{T}_{\mathrm{m}}$ & ${ }^{\circ} \mathrm{C}$ & 13.94 & 34.9 \\
\hline $\begin{array}{l}\text { Potential evapotranspiration } \\
\text { (Hargreaves) }\end{array}$ & $\mathrm{PET}_{\mathrm{H}}$ & $\mathrm{mm} \mathrm{yr}^{-1}$ & 589.50 & 42.6 \\
\hline $\begin{array}{l}\text { Annual accumulated monthly } \\
\text { water deficit (Hargreaves) }\end{array}$ & $\mathrm{AAMWD}_{\mathrm{H}}$ & $\mathrm{mm} \mathrm{yr}^{-1}$ & -103.98 & 43.8 \\
\hline $\begin{array}{l}\text { Annual accumulated monthly } \\
\text { water deficit (Priestley-Taylor) }\end{array}$ & $\mathrm{AAMWD}_{\mathrm{PT}}$ & $\mathrm{mm} \mathrm{yr}^{-1}$ & -45.14 & 44.1 \\
\hline $\begin{array}{l}\text { Potential evapotranspiration } \\
\text { (Priestley-Taylor) }\end{array}$ & $\mathrm{PET}_{\mathrm{PT}}$ & $m m y^{-1}$ & 405.84 & 45.8 \\
\hline Thornthwaite-Mather Index & TMI & no units & 0.37 & 46.7 \\
\hline Accumulated temperature & $\mathrm{T}_{\mathrm{ac}}$ & ${ }^{\circ} \mathrm{D}$ & 3150.60 & 49.8 \\
\hline Mean temperature & $\mathrm{T}$ & ${ }^{\circ} \mathrm{C}$ & 8.61 & 50.0 \\
\hline Total precipitation & $P$ & $\mathrm{~mm} \mathrm{yr}^{-1}$ & 898.71 & 50.9 \\
\hline $\begin{array}{l}\text { Potential evapotranspriation } \\
\text { (Thornthwaite) }\end{array}$ & $\mathrm{PET}_{\mathrm{Th}}$ & $\mathrm{mm} \mathrm{y^{-1 }}$ & 596.24 & 51.1 \\
\hline $\begin{array}{l}\text { Annual accumulated monthly } \\
\text { water deficit (Thornthwaite) }\end{array}$ & $\mathrm{AAMWD}_{\mathrm{Th}}$ & $\mathrm{mm} \mathrm{yr}^{-1}$ & -102.90 & 52.8 \\
\hline Continentality & $\mathrm{C}$ & ${ }^{\circ} \mathrm{C}$ & 18.63 & 55.0 \\
\hline Minimum temperature & $\mathrm{T}_{\min }$ & ${ }^{\circ} \mathrm{C}$ & 1.64 & 75.6 \\
\hline Raindays $^{\mathrm{a}}$ & $\mathrm{RD}$ & $\mathrm{d} \mathrm{yr}^{-1}$ & 156 & 18.0 \\
\hline
\end{tabular}


The BCEMs with continuous outputs (i.e. BBOGGLM, BBOG-GAM, LM-GLM) were used to rank different geographic regions based on their relative position within the defined bioclimatic space. For each BCEM, the continuous output for each $5 \mathrm{~km}$ grid cell across GB was ordered from low to high, and reassigned the appropriate quantile value between 0 and 1 for the position within the data. Data were then regrouped based on geographic regions. Regions were then ranked in order of low $(r a n k=1)$ to high $($ rank = 20) based on the median quantile value for all the $5 \mathrm{~km}$ grid cells within each region. As each region varied in size from 325 to $19350 \mathrm{~km}^{2}$, the median value was chosen to provide the most consistent simple statistic describing the relative position of each region within the bioclimatic space. Although there is inherent variability within each region, these rankings give a simple overview of which regions were relatively closer to the lower limit of the defined bioclimatic space.

Model sensitivity analysis was carried out with respect to each of the 3 input climate variables: temperature, precipitation and cloud cover. Factorial changes for precipitation and cloud cover and difference changes for temperature were applied to the monthly 1961-1990 baseline climate data. The percentage change in the bioclimatic space for each of the models was compared relative to the model fitted to the 1961-1990 climate data.

\section{RESULTS}

\subsection{Calibration}

The threshold model (BBOG) chosen was based on expert judgement about peat formation. As peat formation is primarily controlled by saturation associated with a positive water balance (Wieder \& Vitt 2006), the annual accumulated monthly water deficit (AAMWD) was selected (Table 1, Fig. 1b) in preference to maximum temperature, even though the threshold based on maximum temperature contained a smaller area where blanket peat was predicted to be absent (Table 2). Priestley-Taylor (threshold value $-45.1 \mathrm{~mm} \mathrm{yr}^{-1}$ ) was chosen in preference to Hargreaves to compute AAMWD. While the results were similar, PriestleyTaylor is more physically based (Table 2). Although used only for comparison, raindays was the single variable $\left(>156 \mathrm{~d} \mathrm{yr}^{-1}\right)$ that had the smallest area with no blanket peat cover (18\%, Table 2$)$.

Regression tree analysis of all climatic variables (excluding raindays) identified maximum temperature, TMI and AAMWD, using Priestley-Taylor evaporation, as explanatory variables (BBOG-TREE; see Fig. S1, available at www.int-res.com/articles/suppl/c045p131_

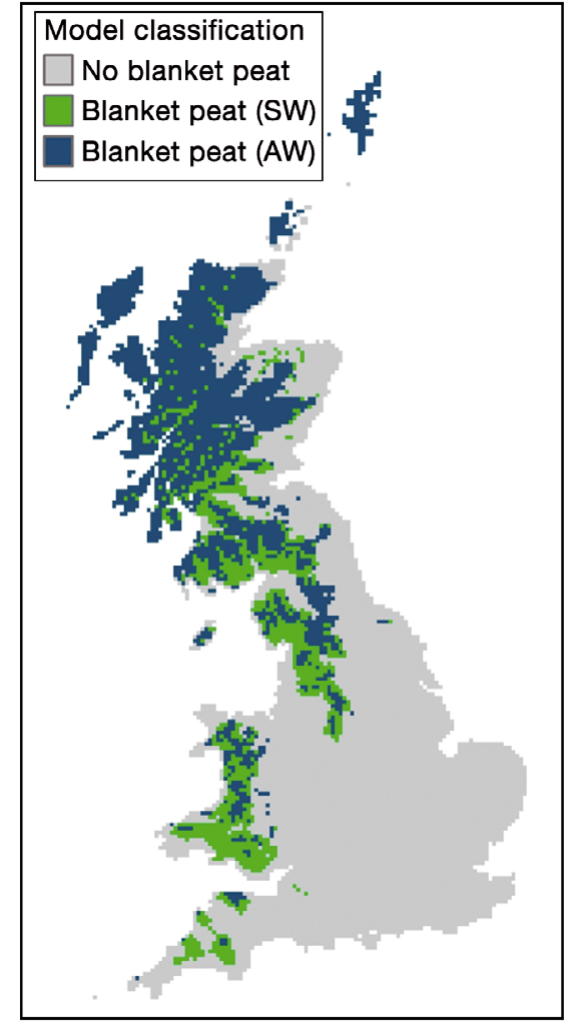

Fig. 2. BBOG-TREE classification of blanket peat area using baseline climate data (1961-1990). AW: areas classified on the basis of an annual wetness index (Thornthwaite-Mather Index); SW: areas classified on the basis of seasonal wetness index (annual accumulated monthly water deficit). BBOGTREE is defined in Table 1

supp.pdf). Probability of blanket peat presence was replaced by a classification based on a presence/ absence within the tree. A 3-level model was chosen as this had a lower misclassification rate for the blanket peat area ( $8.9 \%$ of blanket peat area) than the 5 -level model selected automatically $(12.5 \%$ of blanket peat area). Data were first split based on maximum temperature (threshold $17.4^{\circ} \mathrm{C}$ ). In the group where maximum temperature was $<17.4^{\circ} \mathrm{C}$, blanket peat areas were classified where the TMI $>0.41$ (i.e. in the 'wettest' areas within this group based on an annual index). In the group where maximum temperature was $>17.4^{\circ} \mathrm{C}$, blanket peat areas were found where the AAMWD (estimated using the Priestley-Taylor equation) was $>-28.6 \mathrm{~mm} \mathrm{yr}^{-1}$. Therefore, in the 'warmer' areas a seasonal index of 'wetness' was selected to identify blanket peat areas, whereas an annual 'wetness' index was selected to identify blanket peat in cooler areas (Table 1, Fig. 2).

Backward selection of explanatory variables by logistic regression found the following significant regression parameters $(p<0.01)$ : precipitation, mean 
temperature, accumulated temperature, minimum temperature, maximum monthly mean temperature, TMI and PET estimated using the Thornthwaite equation. Many of these variables represent similar factors (e.g. mean temperature and accumulated temperature), therefore further selection and simplification of the model was carried out by combining data that were not directly related (e.g. precipitation and temperature). Of the possible combinations of variables, monthly maximum mean temperature $\left(\mathrm{T}_{\mathrm{m}}\right)$ and TMI resulted in the lowest AIC (AIC = 2890) (BBOG-GLM; Table 1, Fig. 1c). Similar stepwise backward selection using the GAM model found a different combination of significant explanatory variables: minimum temperature, accumulated temperature, continentality, TMI and PET estimated using the Hargreaves and Priestley-Taylor equations ( $p<0.001)$. As in the GLM analysis, meaningful combinations of variables were again explored, with the most parsimonious model with significant regression parameters selected as minimum temperature, continentality and TMI (BBOG-GAM; Table 1, Fig. 1d).

For comparison, GLM and GAM models were fitted to the climate variables used by Lindsay et al. (1988). Significant regression model fits $(p<0.0001)$ within similar AIC values were obtained with GLM models fitted using all raindays, $\mathrm{P}$ and $\mathrm{T}_{\mathrm{m}}(\mathrm{AIC}=2796)$ and $\mathrm{a}$ modified version with $\mathrm{P}$ and $\mathrm{T}_{\mathrm{m}}$ and raindays excluded $($ AIC $=2971$ ) (Table 1), suggesting these models were similar to both BBOG-GLM and BBOG-GAM in terms of their fit to the mapped area of blanket peat and 1961-1990 baseline climate data used in the calibration data set.

Table 3. Assessment of bioclimatic envelope model fit to the blanket peat verification data set. Threshold cover for $95 \%$ blanket peat area in calibration data set was chosen for the continuous probability models. Models are described in Table 1. P65 $5_{\mathrm{H}}, \mathrm{P} 65_{\mathrm{PT}}$ and $\mathrm{P} 65_{\mathrm{Th}}$ are calculated using Hargreaves, Priestley-Taylor and Thornthwaite evaporation models, respectively. AUC: area under a relative operating characteristic curve; $\mathrm{D}^{2}$ : residual deviance squared

\begin{tabular}{|lcccccc|}
\hline Model & \multirow{2}{*}{$\begin{array}{c}\text { Threshold } \\
(0<\mathrm{P}(\mathrm{BP})<1)\end{array}$} & $\begin{array}{c}\text { Determined for threshold value } \\
\text { Sensitivity }(\%)\end{array}$ & Accuracy $(\%)$ & Kappa & \\
\hline P50 & - & - & 66.1 & 83.6 & 0.59 & - \\
P65 & - & - & 34.1 & 79.5 & 0.40 & - \\
P65 & - & - & 81.4 & 88.3 & 0.72 & - \\
P65 & - & - & 42.7 & 81.9 & 0.49 & - \\
L & - & - & 86.2 & 89 & 0.75 & - \\
LM & - & - & 89.3 & 87.9 & 0.73 & - \\
BBOG & - & - & 96.1 & 83.3 & 0.65 & - \\
BBOG-TREE & - & - & 91.2 & 87.5 & 0.72 & - \\
H-GLM & - & 0.18 & 96.1 & 74.4 & 0.50 & 0.90 \\
L-GLM & 66.5 & 0.24 & 94.3 & 90.4 & 0.78 & 0.97 \\
L-GAM & 69.0 & 0.27 & 94.7 & 90.8 & 0.79 & 0.97 \\
LM-GLM & 64.4 & 0.25 & 94.6 & 90.4 & 0.79 & 0.97 \\
LM-GAM & 67.5 & 0.28 & 94.9 & 91.1 & 0.80 & 0.97 \\
BBOG-GLM & 65.4 & 0.27 & 94.7 & 90.6 & 0.79 & 0.97 \\
BBOG-GAM & 67.6 & 0.27 & 95 & 90.6 & 0.79 & 0.97 \\
\hline
\end{tabular}

\subsection{Comparison of model fit to baseline climate (1961-1990)}

In general, GLM and GAM models performed better than the threshold and classification tree models in terms of the ability to correctly predict blanket peat presence and absence, with greater sensitivity, accuracy and Kappa (Table 3). BBOG-GLM and BBOGGAM had similar classification accuracy (accuracy $90.6 \%$, Kappa 0.79), which were greater than BBOGTREE (accuracy 87.5\%, Kappa 0.72) and BBOG (accuracy $83.3 \%$, Kappa 0.65). The maps showing the area of blanket peat covered by each envelope model show that BBOG and BBOG-TREE did not cover parts of northeast Scotland and Orkney, whereas BBOGGLM and BBOG-GAM show good cover across the country (Fig. 3a-d).

Both the GLM and GAM fits to the data using the variables from the original and modified Lindsay models (L and LM, respectively) were similar (accuracy 90.4 to $91.1 \%$; Kappa 0.78 to 0.80 ) and greater than the threshold based models (accuracy 83.3 to $89 \%$; Kappa 0.73 to 0.75 ), although the differences were small. As with the BBOG models, both threshold based L and LM models did cover parts of north and east Scotland, and also northeast England (Fig. 3e-h). As LM models appeared to provide a comparable fit to the original models, L, L-GLM and L-GAM were not used further due to the absence of projected changes in raindays.

Whilst the H-GLM model threshold was chosen so that it covered $95 \%$ of the blanket peat area, with high sensitivity (96.1\%), the accuracy and Kappa were low, as most of northern GB rather than just upland areas were covered by the model (Fig. 3i). A low sensitivity (66.1\%) and low Kappa (0.59) for the rainfall based threshold model (P50), leaves a large area of mapped blanket peat uncovered to the east (Fig. 3j). Of the possible precipitation/potential evaporation models, P65 $5_{\mathrm{PT}}$ (i.e. evaporation calculated using the Priestley-Taylor model) provided the best fit (Fig. 3k) and was similar to the L and LM threshold models (accuracy 88.3\%， Kappa 0.72). P65 and $\mathrm{P}_{65}$ (Fig. 31 and not shown, respectively) produced a poor fit to the currently mapped data and were not used further. 


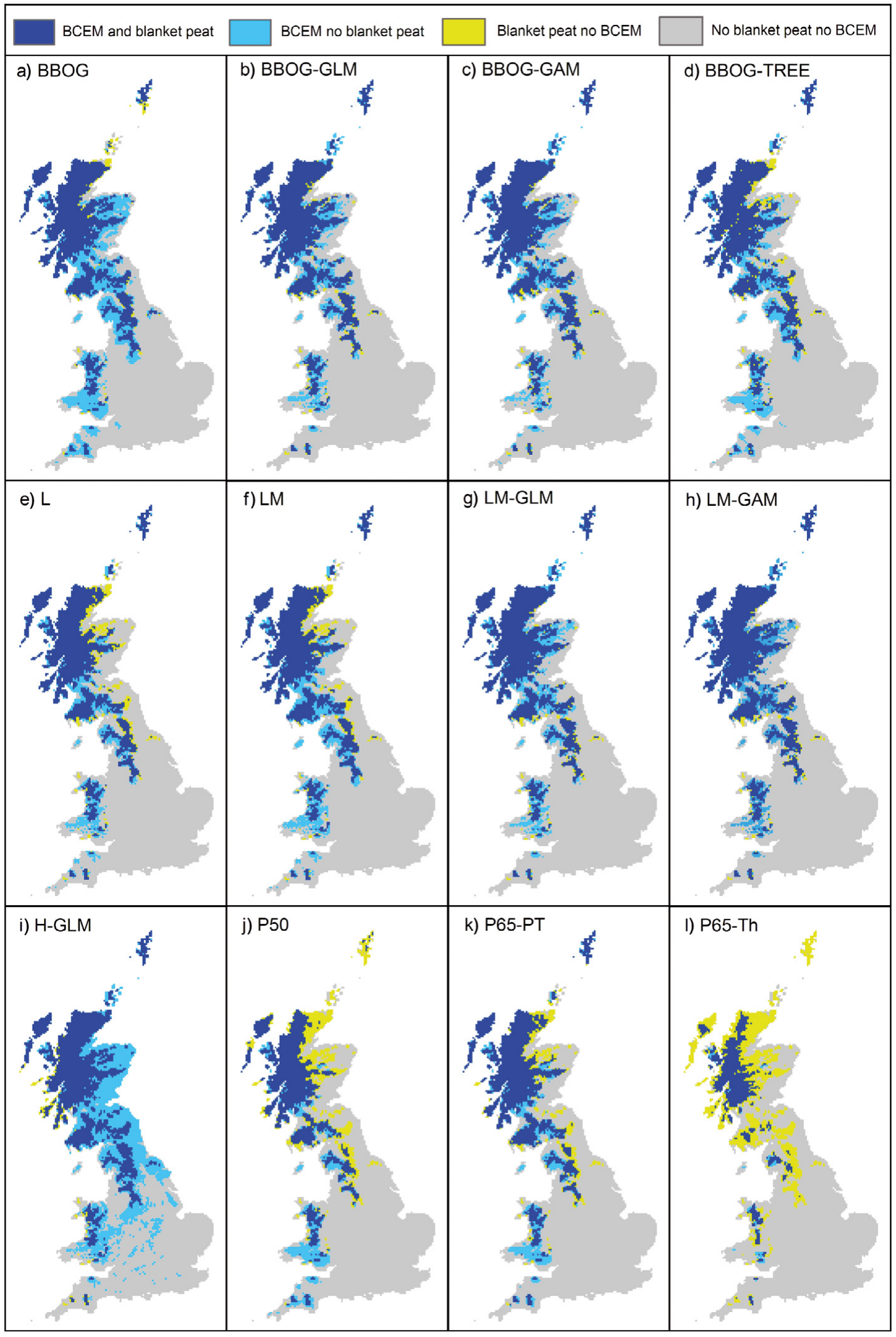

Fig. 3. Overlay of different bioclimatic envelope models (BCEMs) for baseline climate period (1961-1990) on the mapped $5 \mathrm{~km}$ gridded data of blanket peat presence. Envelope models are described in Table 1 


\subsection{Sensitivity analysis}

Simple sensitivity analysis of the 10 best fitting models to independent changes in precipitation, temperature, and cloud cover broadly showed the climate space to decline with decreasing precipitation, increasing temperature and decreasing cloud cover (Fig. 4). BBOG-GLM and BBOG-GAM showed similar responses to changes in precipitation and temperature in spite of the differences in climatic variables used (Table 1). BBOG-TREE and BBOG were slightly more sensitive to changes in precipitation than BBOG-GLM and BBOG-GAM, and considerably less sensitive to change in temperature. LM, LM-GLM and LM-GAM also showed similar response to changes in precipitation and temperature $<+4^{\circ} \mathrm{C}$. Although the same variables were used, the model structures were subtly different. At a temperature change $>+4^{\circ} \mathrm{C}$, LMGAM showed an increase in bioclimatic space. This result seems to be counter intuitive and is probably due to over fitting the GAM model to the observed data, such that results become unrealistic once temperatures go beyond the data within the fitted range. Hence, LM-GAM was not used for further analysis. The only 3 models that show sensitivity to changes in cloud cover are the models using the Priestley-Taylor PET model.
The comparative sensitivity of each BCEM with respect to the fit to the 1961-1990 base line climate data can be considered by comparing the 'LD50'; that is the amount of climate change (or 'lethal dose') needed to cause a reduction in the climate space so that only $50 \%$ of the $5 \mathrm{~km}$ grid cells with blanket peat presence are covered (Table S1, available at www.int-res.com/ articles/suppl/c045p131_supp.pdf). In terms of precipitation change, the precipitation based models P50 and P65 $5_{\text {PT }}$ were most sensitive ( -13 to $-22 \%$ decline), although that is in part because these areas cover a lower proportion of blanket peat (67 to $82 \%$ ). The other threshold modes, LM, BBOG and BBOG-TREE, which covered slightly larger areas (89 to $95 \%$ ) require a change in precipitation of -30 to $-32 \%$ before reaching the 'LD50'. BBOG-GLM and BBOG-GAM required the greatest change $(-43$ to $-46 \%)$ although they covered larger areas (95\%). However, BBOG-GLM, BBOGGAM, H-GLM and LM required a smaller change in temperature $\left(+1.8\right.$ to $\left.2.2^{\circ} \mathrm{C}\right)$ than $\mathrm{BBOG}, \mathrm{BBOG}$-TREE and $\mathrm{P} 65_{\mathrm{PT}}\left(+8.2\right.$ to $\left.11^{\circ} \mathrm{C}\right)$ to be reduced to $50 \%$ cover of the grid cells where blanket peat was present. So in general, in spite of covering a smaller number of blanket peat grid cells under 1961-1990 baseline climate data, the threshold-based models were more sensitive than the GLM and GAM models to changes in precipitation and less sensitive to changes in temperature.
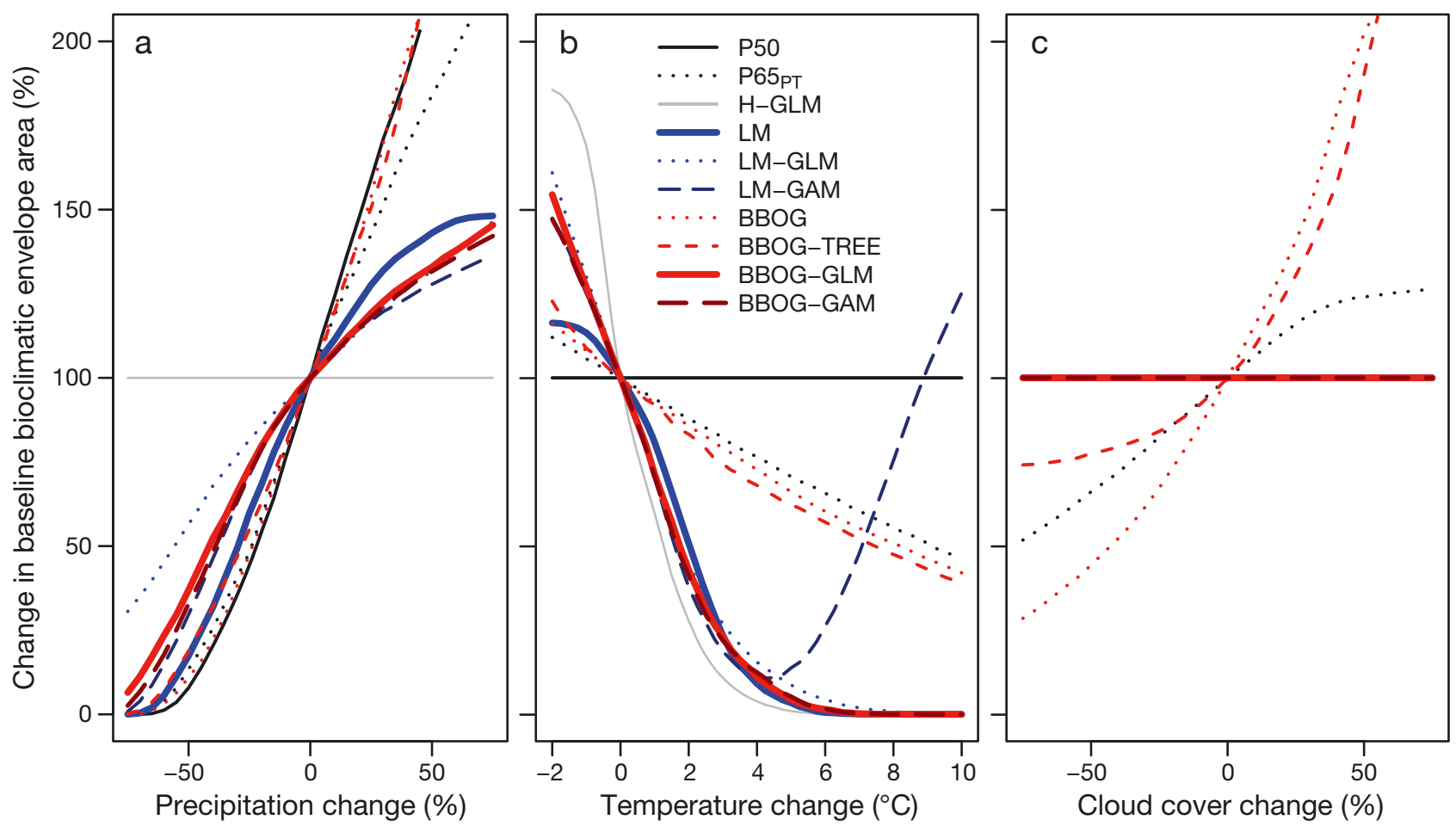

Fig. 4. Sensitivity analysis of bioclimatic envelope models for a single fixed change in either (a) precipitation (b) temperature or (c) cloud cover to 1961-1990 baseline climate data. Changes were applied as single values to the mean monthly data. Models are defined in Tables $1 \& 3$ 
Table 4. Mapped peat area and rank of climatic vulnerability by region. Ranks based on order of median quantiles for each continuous bioclimatic envelope model output from the baseline (1961-1990) climate data (see Fig. 4). Rank 1 is at the lower limit of the bioclimatic space and Rank 20 is at the upper limit of bioclimatic space. Fig. S2 (available at www.int-res.com/articles/suppl/ c045p131_supp.pdf) delineates the blanket peat regions. E: England; W: Wales; S: Scotland

\begin{tabular}{|c|c|c|c|c|c|c|c|c|}
\hline \multirow{2}{*}{\multicolumn{3}{|c|}{ Country and Region }} & \multirow{2}{*}{\multicolumn{2}{|c|}{$\begin{array}{l}\text { Mapped blanket peat area } \\
\left(\mathrm{km}^{2}\right) \quad \text { (\% of total) }\end{array}$}} & \multirow{2}{*}{\multicolumn{4}{|c|}{ Rank order based on BCEM -}} \\
\hline & & & & & & & & \\
\hline E & NB & Northumbria & 325 & 2.1 & 1 & 1 & 1 & 1 \\
\hline E & $\mathrm{DE}$ & Dartmoor, Exmoor \& Bodmin moor & 146 & 0.9 & 3 & 3 & 2 & 2 \\
\hline $\mathrm{E}$ & $\mathrm{PD}$ & Peak District & 476 & 3 & 2 & 4 & 3 & 3 \\
\hline W & $\mathrm{BB}$ & Brecon Beacons \& South Wales & 52 & 0.3 & 4 & 2 & 4 & 4 \\
\hline $\mathrm{E}$ & NY & North York Moors & 40 & 0.3 & 6 & 6 & 5 & 5 \\
\hline $\mathrm{S}$ & OR & Orkney & 115 & 0.7 & 5 & 5 & 11 & 6 \\
\hline $\mathrm{S}$ & $\mathrm{CB}$ & Central Belt & 238 & 1.5 & 8 & 7 & 8 & 7 \\
\hline E & NP & North Pennines & 691 & 4.5 & 9 & 11 & 6 & 8 \\
\hline $\mathrm{S}$ & DG & Ayrshire, Dumfries \& Galloway & 1118 & 7.1 & 10 & 9 & 9 & 9 \\
\hline $\mathrm{S}$ & $\mathrm{CS}$ & Caithness \& East Sutherland & 1903 & 12 & 7 & 8 & 15 & 10 \\
\hline $\mathrm{E}$ & YD & Yorkshire Dales \& Bowland & 765 & 4.8 & 11 & 14 & 7 & 11 \\
\hline W & $\mathrm{CM}$ & Cambrian Mountains & 209 & 1.3 & 13 & 10 & 12 & 12 \\
\hline $\mathrm{S}$ & $\mathrm{SB}$ & Scottish Borders & 238 & 2 & 14 & 13 & 10 & 13 \\
\hline W & SN & Snowdonia \& North Wales & 393 & 2.5 & 12 & 12 & 13 & 14 \\
\hline $\mathrm{S}$ & GR & Grampians & 718 & 4.5 & 19 & 15 & 14 & 15 \\
\hline $\mathrm{S}$ & WI & Western Isles & 1366 & 8.6 & 15 & 16 & 19 & 16 \\
\hline $\mathrm{S}$ & $\mathrm{AB}$ & Argyle, Bute \& Trossachs & 2142 & 13.5 & 17 & 17 & 17 & 17 \\
\hline E & $\mathrm{CF}$ & Cumbria Fells \& Dales & 182 & 1.2 & 18 & 18 & 16 & 18 \\
\hline $\mathrm{S}$ & $\mathrm{SH}$ & Shetland & 648 & 4.1 & 16 & 19 & 18 & 19 \\
\hline $\mathrm{S}$ & $\mathrm{HI}$ & Highlands & 3995 & 25.2 & 20 & 20 & 20 & 20 \\
\hline \multicolumn{3}{|c|}{ All } & 15830 & 100 & & & & \\
\hline
\end{tabular}

\subsection{Regional climatic vulnerability}

An understanding of the relative climatic vulnerability of each region within $G B$, independent of choice of GCM and/or emission scenario, could inform policy decisions and blanket peat management, such as prioritisation of restoration work. Although a rough picture of the comparative vulnerability can be seen at a national scale (Figs. 1 \& 2), a more formal assessment is possible. BCEMs providing continuous data can be used to determine the relative vulnerability of each $5 \mathrm{~km}$ grid cell in terms of its relative position in the data set. Therefore, grid cells with values within the lowest 0.05 quantile (or lowest $5 \%$ ) of the data set are sites closest to the lowest limit of the bioclimatic space, and are therefore likely to be more vulnerable to climate change. Individual grid cells can be ranked nationally (Figs. 1 \& 2; Table S2, available at www.int-res.com/ articles/suppl/c045p131_supp.pdf), but an assessment of comparative 'regional' vulnerability may be more useful to decision makers.

Areas were grouped into 20 known geographic regions, with blanket peat cover ranging from 52 to $3995 \mathrm{~km}^{2}$ within each region (Fig. S2, Table S3, both available at www.int-res.com/articles/suppl/c045p131_ supp.pdf). Ranked output from the continuous probability models, BBOG-GLM, BBOG-GAM and LM-GLM were aggregated to provide an overall regional vulner- ability (Table 4). Although based on a continuous variable, BBOG could not be used as it was not possible to rank sites above the median distribution as many cells had the same value of $0 \mathrm{~mm} \mathrm{yr}^{-1}$ (Table S1). H-GLM was not used, given the large overestimation of area (Fig. 3). In general, BBOG-GLM, BBOG-GAM and LM-GLM produced similar, although not identical, regional rankings with Northumbria (NB) found at the lowest end of the bioclimatic space and the Highlands (HI) found at the top (Table 4, Fig. 5). Dartmoor, Exmoor and Bodmin moor (DE), the Peak District (PD), the Brecon Beacons and South Wales (BB) were also consistently found in the lower 5 ranks, suggesting these regions are perhaps the most climatically vulnerable as they are at the lower edge of the bioclimatic space. In contrast the Shetland (SH), Western Isles (WI), Argyle, Bute and Trossachs (AB) and Cumbria Fells and Dales (CF) were consistently found in the upper 5 ranks, and are perhaps relatively the least vulnerable, as they are at the upper edge of the defined bioclimatic space.

Although a southeast-northwest gradient might be expected in vulnerability, as temperatures typically fall and rainfall increases in the north and west of GB, regional vulnerability does not necessarily follow this exact pattern. For instance, the North York Moors and Orkney are ranked 5 and 6, respectively, in spite of distances between each region; similarly, Caithness and 

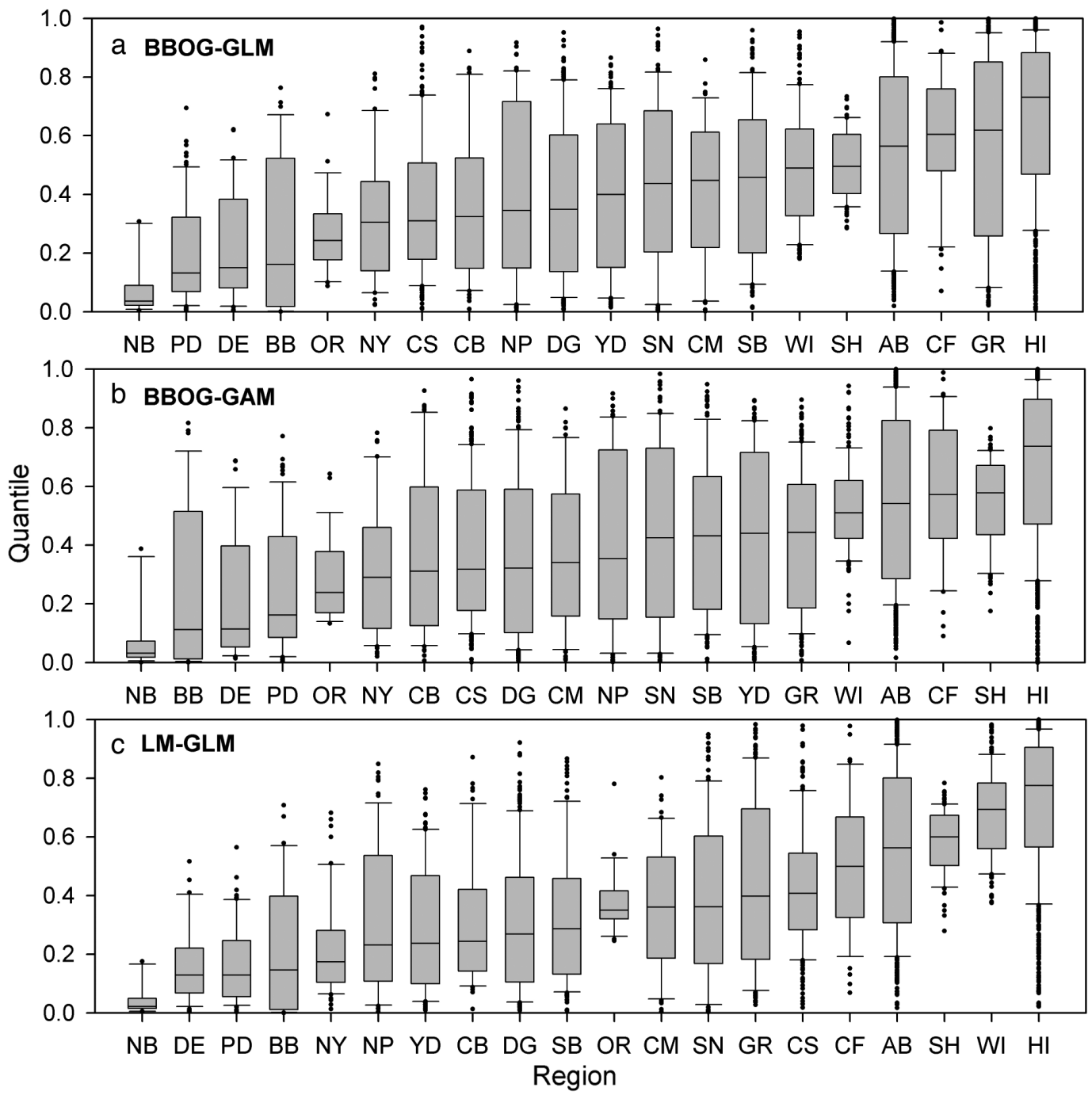

Fig. 5. Rank of the bioclimatic space covered by 3 continuous bioclimatic envelope models (BCEM) models. Quantile values closer to 0 are at the lower limit of the bioclimatic space (i.e. most marginal areas), and quantile values closer to 1 are towards to upper limit of the bioclimatic space. Boxes: interquartile range; whiskers: 5th and 95th percentiles; dots: outliers. Regions are defined in Table 4 and shown in Fig. S2 (available at www.int-res.com/articles/suppl/c045p131_supp.pdf)

East Sutherland were ranked alongside Yorkshire Dales and Bowland as Rank 10 and 11, respectively (Table 4). However, these rankings are based on median values, and many regions contain grid cells within the lowest $20 \%$, therefore including potentially vulnerable areas of blanket peat. Table S2 can be used for a more detailed assessment of specific $5 \mathrm{~km}$ sites to investigate within-region heterogeneity.

\subsection{Projected future changes in blanket peat bioclimatic space}

An ensemble of the 8 statistical BCEMs was used to examine possible change in the bioclimatic space asso- ciated with the mapped distribution of blanket peat. The 4 BBOG models were combined with 4 published models (P50, P65 ${ }_{\mathrm{PT}}, \mathrm{H}-\mathrm{GLM}$ and LM). Other tested BCEMs were removed due to poor fit or double counting of combinations of climate variables (e.g. LM and LM-GM). Together, they represent a range of possible outcomes, given the problem that all these models could be calibrated to provide a similar fit to the blanket peat map using the baseline climate data (Fig. 3).

Response to UKCIP02 projections for high and low emission scenarios showed a general retreat in the bioclimatic space to the north and west (Fig. 6). The models that were most sensitive to changes in temperature showed retreat to the high altitude areas towards the north (e.g. BBOG-GLM, BBOG-GAM, LM, H-GLM), 


\section{Number of bioclimatic envelope models covering each $5 \mathrm{~km}$ grid cell}

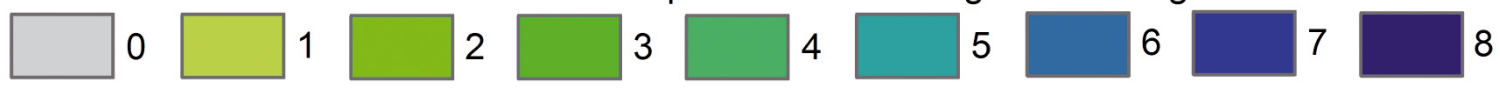

UKCIP02 High Emissions Scenario

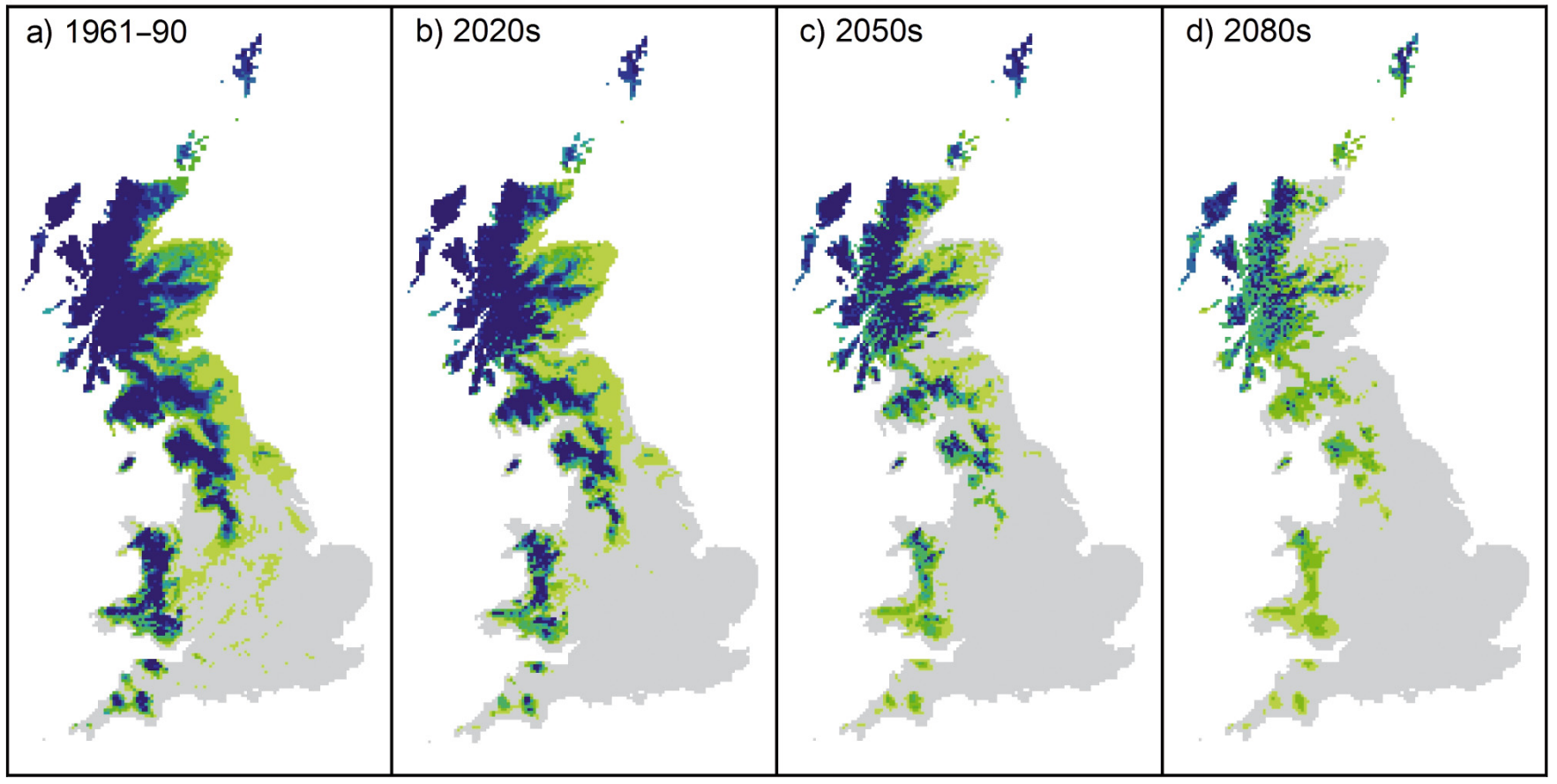

UKCIP02 Low Emissions Scenario

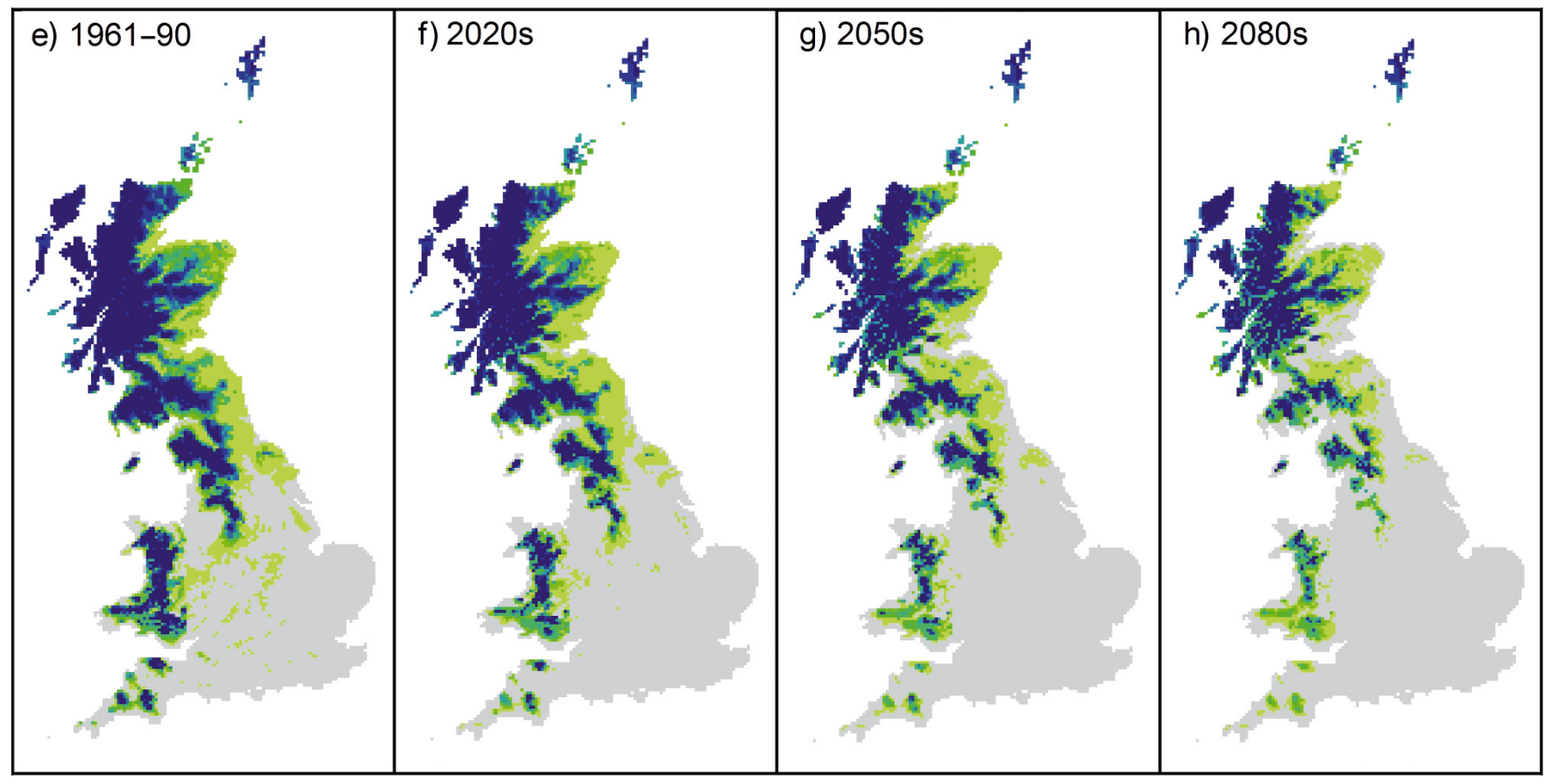

Fig. 6. Projected changes in bioclimatic space associated with the 1961-1990 baseline climate and mapped area of blanket peat using UKCIP02 high and low emissions scenarios. 2020s: 2011-2040; 2050s: 2041-2070; 2080s: 2071-2100. Bioclimatic envelope models used were P50, P65 1 , LM, H-GLM, BBOG, BBOG-TREE, BBOG-GLM, BBOG-GAM (see Tables 1 \& 3 for details). Change in each individual model output is shown in Figs. S3 \& S4 (available at www.int-res.com/articles/suppl/c045p131_supp.pdf) 


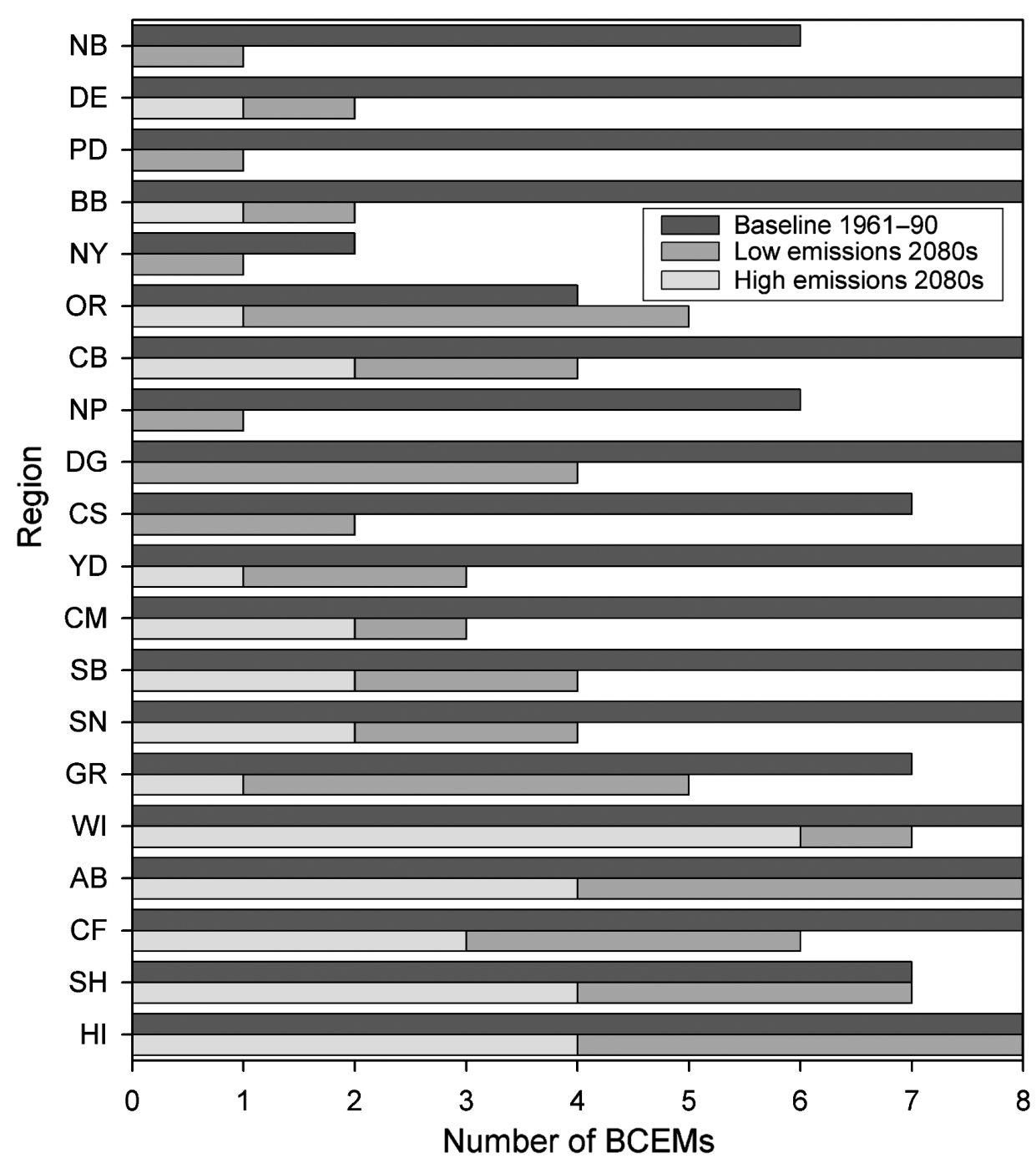

Fig. 7. Number of bioclimatic envelope models (BCEMs) covering at least $50 \%$ of each region using UKCIP02 high and low emission scenarios. 2080s: 2071-2100. BCEMs ordered based on overall ranking shown in Table 4

whereas the models based on water deficit showed a retreat towards the north and west (e.g. BBOG, BBOGTREE, P65 ${ }_{\mathrm{PT}}$ ). The model based on annual precipitation alone showed little change (P50) (see Figs. S3 \& S4, available at www.int-res.com/articles/suppl/c045p131_ supp.pdf).

Projected regional changes broadly followed the pattern of regional sensitivity presented in Table 4, as the 5 regions at the lower end of the bioclimatic space showed the greatest decline in blanket peat presence estimated by the 8-BCEM ensemble; and the 5 regions at the upper end of the climate space showed the least change (Fig. 7). However, there are slight differences as areas such as the North Pennines and Caithness and Sutherland appear to show greater retreat in the BCEM space than areas initially ranked lower like
Orkney and the Central Belt. This difference in response may be due to subtle differences in the ranking approach, as all 8 models for the ensemble were included based on a presence/absence classification rather than quantile of each $5 \mathrm{~km}$ grid cell. In the ranking shown in Fig. 5, North York Moors, Orkney, Northumberland, North Pennines and Caithness and East Sutherland have the lowest initial BCEM cover during 1961-1990, with Caithness and East Sutherland and Orkney replacing the Peak District and Brecon Beacons. However, the difference may also be caused by variation in the magnitude of climate change between regions. For instance, projections for changes in temperature for the Eastern and Southern parts of GB were greater than for other regions of the country (Hulme et al. 2002). 


\section{DISCUSSION}

\subsection{Comparison between 4 BBOG bioclimatic models and other published BCEMs}

Broadly speaking, BCEMs could be split into 2 groups irrespective of structure and climatic variables used: (1) models that were more sensitive to changes in temperature than precipitation and (2) models that were more sensitive to changes in precipitation or 'wetness' than temperature. For instance, BBOG-TREE was more sensitive to changes in rainfall and less sensitive to changes in temperature than BBOG-GLM and BBOG-GAM in spite of containing similar climatic variables and providing a similar fit to the baseline climate and mapped peat area. Also, the threshold and GLM versions of the modified Lindsay et al. (1988) (LM) models showed a similar sensitivity and fit to both BBOG-GLM and BBOG-GAM, even though the climatic variables chosen in each model differed. LM contained precipitation only whereas BBOG-GLM and BBOG-GAM had measures of the balance between precipitation and potential evaporation. However, threshold models based on either precipitation, mean temperature, or the balance between precipitation and evapotranspiration alone did not fit the calibration data as well as models that contained measures of both 'water deficit' and temperature. Although a positive water balance and saturation is essential for peat formation, additional measures of temperature (particularly maximum temperature) were needed to improve the definition of the bioclimatic space associated with blanket peat.

As many of the BCEMs include explicit representations of the water balance, it seems unlikely that inclusion of temperature represents its effects on evapotranspiration alone. Maximum temperature has been identified as an important limiting factor controlling the distribution between upland and lowland grass species (Rodwell et al. 1992), such that warming may have caused invasion of upland areas by lowland species (Hossell et al. 2000) which could have higher rates of transpiration than peatland vegetation and act to 'dry out' the peat. Temperature also influences the rate of organic matter decomposition, which in turn affects carbon turnover and the accumulation of organic matter. Although temperature range (i.e. 'continentality') was identified as a key variable defining blanket peat bioclimatic space globally (Lindsay et al. 1988) and in Fennoscandia (Parviainen \& Luoto 2007), maximum temperature provided a far better predictor for GB blanket peats.

As rainfall is transported from catchment hillslopes to streams within hours of falling (Evans et al. 1999), the distribution of rainfall through the year could be as important as the total amount in maintaining the persistently wet conditions essential for Sphagnum species (Backeus 1988, Lindsay 1995). Exclusion of raindays from the selected BCEMs was unavoidable as raindays were not directly available from climate projections. However, in the initial analysis, raindays emerged as the single most important predictor variable, consistent with other observations (Tansley 1939, Goode \& Ratcliffe 1977, Lindsay et al. 1988). Further development and use of site specific computationally expensive tools like weather generators (e.g. Kilsby et al. 2007) at a wide national scale could improve BCEMs in future. Nevertheless, other combinations of climatic variables were able to provide almost as good a fit. For instance, excluding raindays from the Lindsay et al. (1988) model made little difference to the fit (Fig. 3). Raindays and total precipitation in practice are highly correlated (Clark et al. 2010), therefore precipitation can be used as a proxy for raindays. However, as climate change projections suggest a likely change in the distribution of precipitation throughout the year, with less change in total annual precipitation (Hulme et al. 2002, Jenkins et al. 2009), it is possible that the relationship between raindays and total annual rainfall may change somewhat over time.

\subsection{Climatic vulnerability of blanket bog bioclimatic space}

Seven out of the 8 bioclimatic models used in the ensemble showed a decline in the climate space associated with blanket peat using UKCIP02. Models that were more sensitive to changes in temperature, however this was represented, generally showed a retreat to high altitudes. Models that were more sensitive to changes in the water balance showed a retreat to the north and west following the gradient in precipitation. Threshold models based entirely on precipitation (P50) showed little change. Similarly, models that included total precipitation rather than an explicit measure of water balance followed the pattern of temperaturedriven models. We infer that the retreat shown by the models driven by water balance seems likely to be influenced principally by projections for decreased summer precipitation, given the pattern of retreat and the explicit representation of monthly precipitation within the models calculated using the AAMWD. Paleoclimate studies have shown that the total accumulated seasonal water deficit is comparatively insensitive to changes in potential evaporation and is more sensitive to changes in summer precipitation (Charman 2007).

Given the known dependence of blanket bogs on water saturation for key peatland species, and for the required slow rates of decomposition, it seems likely 
a priori that the water balance-driven BCEM group is the most realistic. However, water balance alone was not able to define the bioclimatic space associated with blanket peat as well as combinations of water balance with temperature. Changes in temperature, particularly maximum temperature, may be (at the least) equally important as a driver of changes in blanket bog distribution. As noted above, changes in temperature could influence both species composition and carbon accumulation.

Interestingly, the finding that maximum temperature was an important explanatory variable within BCEMs is consistent with paleoecological studies, where reconstructions of the surface wetness of GB raised bogs have shown a good relationship with summer temperature over centennial time periods that are likely to be important for net peat accumulation (Barber \& Langdon 2007, Charman et al. 2009). The significance of temperature in comparison to precipitation and water deficit in controlling peatland surface wetness has been a recent topic of debate, with contrasting views (Barber \& Langdon 2007, Charman 2007, Charman et al. 2009, Booth 2010). Higher resolution reconstructions have shown that measures of water deficit, rather than temperature or precipitation alone, are more clearly correlated with surface wetness and reconstructed water table fluctuations over shorter 5 to $10 \mathrm{yr}$ time periods (Charman 2007, Charman et al. 2009, Booth 2010). It is unclear whether climatic variables driving shorter-term water table fluctuations (i.e. water deficit or AAMWD) or longer term measures of surface wetness (i.e. maximum or summer temperature) are more important for net peat accumulation in terms of the relative influence on peatland vegetation and structure relative to net organic matter decomposition. Non-linearities in proxy-climate response can hamper paleoclimate reconstructions, therefore dynamic models accounting for changes in peatland hydrology, accumulation and structure are needed to explore these relationships further (Charman 2007).

Differences between the bioclimatic space defined by temperature- and water balance-based BCEMs may explain some of the subtle differences between the regional ranking shown in Table 4 and Fig. 7. Across the different ranking methods, certain regions were consistently towards the lower limit of the bioclimatic space (e.g. Northumbria, North York Moors and Orkney) and others were towards the upper end (e.g. Highlands, Western Isles and Argyle, Bute and the Trossachs). However, other regions like Dartmoor, Exmoor, the Peak District and the Brecon Beacons did not appear as vulnerable when all 8 BCEMs were used, possibly due to the increased water surplus in these regions relative to others. The North Pennines and Caithness and East Sutherland appeared more vulnerable under the 8-BCEM ranking, and showed a comparable decline in bioclimatic space under projections for the 2080s to the most vulnerable regions.

A reduction in the bioclimatic space associated with blanket peat is consistent with findings of Hossell et al. (2000) under UKCIP98 projections using a GLM model based on mean temperature. However, these findings differ from other BCEM work, where artificial neural networks using measures of soil water deficit and surplus as well as maximum and minimum temperature showed little overall change in blanket bog habitat under the same UKCIP98 scenarios (Berry et al. 2003). Differences between projections here based on UKCIP02 and projections made by Berry et al. (2003) may be due to differences between climate projections, although a difference due to different BCEMs used seems likely. Berry et al. (2003) calibrated their models over a wider geographic area than the BBOG models that were trained solely on GB data. However, Berry et al. (2003) focused on plant species whereas the BBOG models were trained on mapped soil data. Blanket peat soils can be covered by a range of different species that can be found in a range of habitat types, e.g. Sphagnum mosses are found in rain-fed blanket peats and groundwater fed flushes, and Calluna vulgaris can be found on peat, peaty gleys and other organo-mineral soils under peatland and heathland habitats. Therefore, it is possible that species-based BCEMs may cover a wider range of habitat or soils across a broader bioclimatic zone than BCEMs based on soil survey data.

\subsection{Limitations}

Statistical BCEMs presented here are based on derived statistical relationships between the known mapped distribution of blanket peat or blanket bog habitats and climatic variables. While the simplicity of this approach allows for a widespread national assessment of climatic vulnerability, some limitations constrain the interpretation of these model outputs. Most notably, projected changes in the bioclimatic space associated with the current distribution of blanket peat are not the same as projected changes in the actual distribution of blanket peat over the next century; a reduction in the bioclimatic space for blanket peat will not result in the immediate disappearance of blanket peat, which may well persist over decades or longer even if not in a state of active growth.

Another caveat is that statistical relationships with climatic variables do not necessarily imply causal relationships, thus blanket peat distribution may only respond to some of the many climatic drivers used in the ensemble of BCEMs while the real distribution 
may respond to others that were not used, e.g. climatic extremes such as frost and high intensity rainfall, (e.g. Bragazza 2008; Evans \& Warburton 2007).

Climate overall is accepted as the key factor influencing the distribution of rain-fed blanket peat (Wieder \& Vitt 2006), but geology and topography also contribute. Blanket peat tends to form on impermeable rocks or thick layers of glacial till on shallow slopes (typically $<10^{\circ}$, although slopes up to $25^{\circ}$ have been noted) where saturated conditions are allowed to develop because of impeded and/or slow drainage (Taylor 1983). In other wetland areas, topography has been used to map the distribution of saturated areas in topographic hollows and floodplains (Creed et al. 2008, Debella-Gilo \& Etzelmüller 2009). However, blanket peat tends not to be confined to hollows or footslopes and is often found on hill-top plateaus (Taylor 1983).

As noted above the BCEMs have been calibrated against the current mapped distribution of blanket peat. It is currently unknown whether this mapped distribution reflects blanket peat that is in equilibrium with the current climate. Therefore the bioclimatic space calibration within the BBOG models may not reflect the actual bioclimatic envelope for blanket peat sustainability. Once peat initiation has been triggered, peat growth can sustain its own hydrology even in the absence of a suitable climate if the peat mass is in good condition; if not in good condition, peat formation may not re-establish itself in unfavourable climates (Lindsay 1995). Previous work has suggested that some blanket bogs in North Scotland are degrading because the climate has become too dry (Pearsall 1956). Confirmation of peat net accumulation can only be gained from field measurements of net peat accumulation rates using either a paleoecological or mass balance approach. At present, only few such data are available for $\mathrm{GB}$.

Projected changes in the bioclimatic space associated with blanket peat by the BCEMs also do not provide information about the likely changes that may occur or the possible feedbacks that could operate, that could either stabilise the system (negative feedback) or promote change to a new equilibrium (positive feedback). Changes in biotic interactions, seed dispersal and invasive species have been cited as possible limitations with BCEMs (Pearson \& Dawson 2003). Within other peatland systems, manipulation experiments have shown that both temperature and water table elevation (driven by the water balance) affect the competitive balance between different Sphagnum species and between Sphagnum species and other vascular plants (Breeuwer et al. 2008, Robroek et al. 2009). Increased vascular plant cover has also been associated with a decline in Sphagnum, and the possibility of change from peatland to a grassland or heathland system
(Berendse et al. 2001). However, plant succession and change to a new ecosystem depends on the initial state of the peatland, as some states are able to adapt to perturbations, whereas other (drier) initial states are more likely to change in response to perturbation (Strack et al. 2006). Historically, warmer conditions have been associated with an increase in drier hummock-type peatland species that are more productive and build peat at a faster rate than the wetter peat species (Barber 1981, Lindsay et al. 1988). Manipulation studies in Finland have also found increased carbon accumulation in response to drainage (Laiho et al. 2003). Climate change may result in blanket peat being replaced by another mire type with the same peat characteristics, but different structural and hydromorphological features (Lindsay et al. 1988). In more degraded and drier sites, it may result in ecological succession, and in terms of soil formation a shift to a peaty podzol or other shallow organic soil. The strength of predictions made with BCEMs and climatic projections is that they show the potential for change, and the regions where change is most likely to occur; however their limitation is that they do not realistically represent the actual magnitude or exact nature of this change.

Acknowledgements. This research was funded by the Environment Agency (Science Project Sc070036) and NERCQUEST research programme, which funded J.M.C., A.V.G.S. and J.I.H. J.M.C. was also funded by a fellowship from the Grantham Institute for Climate Change, Imperial College London. P.S. is a Royal Society-Wolfson Research Merit Award holder. The views expressed are those of the authors and do not necessarily represent the position of the funding bodies. We thank the Met Office for use of their gridded climate data; the UK Climate Impact Programme for providing future climate projections; Russell Lawley for useful discussion regarding blanket peat mapping; contributions made by the wider EA-QUEST Uplands project network (which includes over 50 researchers and policy makers) during workshops and other discussions, and 2 anonymous reviewers for their helpful comments on the manuscript.

\section{LITERATURE CITED}

Allen RG, Pereira LS, Raes D, Smith M (1998) Crop evapotranspiration: guidelines for computing crop water requirements. FAO Irrigation and drainage paper 56. FAO, Rome

Armstrong A, Holden J, Kay P, Foulger M, Gledhill S, McDonald AT, Walker A (2009) Drain-blocking techniques on blanket peat: a framework for best practice. J Environ Manag 90:3512-3519

Avery BW (1980) Soil classification for England and Wales (Higher Categories). Soil Survey of England and Wales, Harpenden

Backeus I (1988) Weather variables as predictors of Sphagnum growth on a bog. Holarct Ecol 11:146-150

Barber KE (1981) Peat stratigraphy and climatic change: a palaeoecological test of the theory of cyclic peat bog regeneration. Balkema, Rotterdam

Barber KE, Langdon PG (2007) What drives the peat-based 
paleoclimate record? A critical test using multiproxy climate records from northern Britain. Quat Sci Rev 26: 3318-3327

Berendse F, Van Breemen N, Rydin H, Buttler A and others (2001) Raised atmospheric $\mathrm{CO}_{2}$ levels and increased $\mathrm{N}$ deposition cause shifts in plant species composition and production in Sphagnum bogs. Glob Change Biol 7:591-598

Berry PM, Dawson TP, Harrison PA, Pearson R, Butt N (2003) The sensitivity and vulnerability of terrestrial habitats and species in Britain and Ireland to climate change. $J$ Nat Conserv 11:15-23

Booth RK (2010) Testing the climate sensitivity of peat-based paleoclimate reconstructions in mid-continental North America. Quat Sci Rev 29:720-731

Bragazza L (2008) A climatic threshold triggers the die-off of peat mosses during an extreme heat wave. Glob Change Biol 14:2688-2695

Bragg OM, Tallis JH (2001) The sensitivity of peat-covered upland landscapes. Catena 42:345-360

Breeuwer A, Heijmans M, Robroek BJM, Berendse F (2008) The effect of temperature on growth and competition between Sphagnum species. Oecologia 156:155-167

> Chapman SJ, Bell J, Donnelly D, Lilly A (2009) Carbon stocks in Scottish peatlands. Soil Use Manag 25:105-112

Charman DJ (2007) Summer water deficit variability controls on peatland water-table changes: implications for Holocene palaeoclimate reconstructions. Holocene 17:217-227

> Charman DJ, Barber KE, Blaauw M, Langdon PG and others (2009) Climate drivers for peatland palaeoclimate records. Quat Sci Rev 28:1811-1819

Clark JM, Orr HG, Freer J, House J, Smith P, Freeman C (2010) Assessment of projected changes in upland environments using simple climatic indices. Clim Res 45:87-104

Clayden B, Hollis JM (1984) Criteria for differentiating soil series (TM17). Soil Survey of England and Wales, Harpenden

Clymo RS (1984) Sphagnum-dominated peat bog: a naturally acid ecosystem. Philos Trans R Soc Lond B Biol Sci 305: $487-499$

> Cohen J (1960) A coefficient of agreement for nominal scales. Educ Psychol Meas 20:37-46

$>$ Creed IF, Beall FD, Clair TA, Dillon PJ, Hesslein RH (2008) Predicting export of dissolved organic carbon from forested catchments in glaciated landscapes with shallow soils. Global Biogeochem Cycles 22:GB4024 doi:10.1029/ 2008GB003294

Davies GM, Gray A, Hamilton A, Legg CJ (2008) The future of fire management in the British uplands. Int J Biodivers Sci Manag 4:127-147

> Debella-Gilo M, Etzelmüller B (2009) Spatial prediction of soil classes using digital terrain analysis and multinomial logistic regression modeling integrated in GIS: examples from Vestfold County, Norway. Catena 77:8-18

Ellis CJ, Coppins BJ, Dawson TP, Seaward MRD (2007) Response of British lichens to climate change scenarios: trends and uncertainties in the projected impact for contrasting biogeographic groups. Biol Conserv 140:217-235

Evans M, Warburton J (2007) Geomorphology of upland peat: erosion, form and landscape change. Blackwell, Oxford

Evans MG, Burt TP, Holden J, Adamson JK (1999) Runoff generation and water table fluctuations in blanket peat: evidence from UK data spanning the dry summer of 1995. J Hydrol 221:141-160

Evans M, Warburton J, Yang J (2006) Eroding blanket peat catchments: global and local implications of upland organic sediment budgets. Geomorphology 79:45-57

> Fronzek S, Luoto M, Carter TR (2006) Potential effect of climate change on the distribution of palsa mires in subarctic
Fennoscandia. Clim Res 32:1-12

Gignac LD, Nicholson BJ, Bayley SE (1998) The utilization of bryophytes in bioclimatic modeling: predicted northward migration of peatlands in the Mackenzie River Basin, Canada, as a result of global warming. Bryologist 101: 572-587

Gignac LD, Halsey LA, Vitt DH (2000) A bioclimatic model for the distribution of Sphagnum-dominated peatlands in North America under present climatic conditions. J Biogeogr 27:1139-1151

Goode DA, Ratcliffe DA (1977) Peatlands. In: Ratcliffe DA (ed) A nature conservation review. Cambridge University Press, Cambridge

Gregory S (1954) Accumulated temperature maps of the British Isles. Trans Inst Br Geogr 20:59-73

Guisan A, Zimmermann NE (2000) Predictive habitat distribution models in ecology. Ecol Model 135:147-186

- Hargreaves GL, Hargreaves GH, Riley JP (1985) Irrigation water requirements for Senegal river basin. J Irrig Drainage Eng ASCE 111:265-275

Heathwaite AL (1993) Disappearing peat - regenerating peat: the impact of climate change on British peatlands. Geogr J 159:203-208

Heikkinen RK, Luoto M, Araujo MB, Virkkala R, Thuiller W, Sykes MT (2006) Methods and uncertainties in bioclimatic envelope modelling under climate change. Prog Phys Geogr 30:751-777

Hossell JE, Briggs B, Hepburn IR (2000) Climate change and UK nature conservation: a review of the impact of climate change on UK species and habitat conservation policy. Department of the Environment, Transport and the Regions, London

Hulme M, Jenkins GL, Lu X, Turnpenny JR and others (2002) Climate change scenarios for the United Kingdom: the UKCIP02 Scientific Report. Tyndall Centre for Climate Change Research, School of Environmental Sciences, University of East Anglia, Norwich

IPCC (2000) Special report on emissions scenarios (SRES): a special report of Working Group III of the Intergovernmental Panel on Climate Change. Cambridge University Press, Cambridge

Jenkins GJ, Murphy JM, Sexton DS, Lowe JA, Jones P, Kilsby CG (2009) UK climate projections: briefing report. Met Office Hadley Centre, Exeter

> Kay AL, Davies HN (2008) Calculating potential evaporation from climate model data: a source of uncertainty for hydrological climate change impacts. J Hydrol 358: 221-239

Kilsby CG, Jones PD, Burton A, Ford AC and others (2007) A daily weather generator for use in climate change studies. Environ Model Softw 22:1705-1719

Laiho R, Vasander H, Penttila T, Laine J (2003) Dynamics of plant-mediated organic matter and nutrient cycling following water-level drawdown in boreal peatlands. Global Biogeochem Cycles 17:1053 doi:10.1029/2002GB002015

Lindsay RA (1995) Bogs: the ecology, classification and conservation of ombrotrophic mires. Scottish Natural Heritage, Battleby

Lindsay RA, Charman DJ, Everingham F, O'Reilly RM, Palmer MA, Rowell TA, Stroud DA (1988) The Flow Country: the peatlands of Caithness and Sutherland. Nature Conservancy Council, Peterborough

Malmer N (1992) Peat accumulation and the global carbon cycle. In: Boer M, Koster E (eds) Greenhouse-Impact on Cold-Climate Ecosystems and Landscapes. Selected papers of the European Conference on Landscape Ecological Impact of Climatic Change, Lunteren, The Netherlands, 
Dec 3-7, 1989. Catena Suppl 22:97-110

Mather JR (1978) The climatic water budget in environmental analysis. Lexington Books, Toronto

Milne R, Brown TA (1997) Carbon in the vegetation and soils of Great Britain. J Environ Manag 49:413-433

Monserud RA, Leemans R (1992) Comparing global vegetation maps with the Kappa statistic. Ecol Model 62:275-293

Moore PD, Bellamy DJ (1973) Peatlands. Unwin Brothers, Woking

Murphy J, Sexton D, Jenkins G, Boorman P and others (2009) UK climate projections science report: climate change projections. Met Office Hadley Centre, Exeter

Parviainen M, Luoto M (2007) Climate envelopes of mire complex types in Fennoscandia. Geogr Ann Ser A Phys Geogr 89A:137-151

$>$ Pearce J, Ferrier S (2000) Evaluating the predictive performance of habitat models developed using logistic regression. Ecol Model 133:225-245

Pearsall WH (1950) Mountains and moorlands. Collins, London

Pearsall WH (1956) Two blanket-bogs in Sutherland. J Ecol 44:493-516

Pearsall WH (1965) Mountains and moorlands. Bloomsberry Books, London

Pearson RG, Dawson TP (2003) Predicting the impacts of climate change on the distribution of species: are bioclimate envelope models useful? Glob Ecol Biogeogr 12:361-371

Perry M, Hollis D (2005) The generation of monthly gridded datasets for a range of climatic variables over the UK. Int $\mathrm{J}$ Climatol 25:1041-1054

Priestley CHB, Taylor RJ (1972) Assessment of surface heat flux and evaporation using large scale parameters. Mon Weather Rev 100:81-92

Ramchunder SJ, Brown LE, Holden J (2009) Environmental effects of drainage, drain-blocking and prescribed vegetation burning in UK upland peatlands. Prog Phys Geogr 33: 49-79

Robroek BJM, Schouten MGC, Limpens J, Berendse F,

Submitted: February 9, 2010; Accepted: August 29, 2010
Poorter H (2009) Interactive effects of water table and precipitation on net $\mathrm{CO}_{2}$ assimilation of 3 co-occurring sphagnum mosses differing in distribution above the water table. Glob Change Biol 15:680-691

Rodwell JS, Pigott CD, Ratcliffe DA, Malloch AJC and others (1992) British plant communities, Vol 3. grasslands and montane communities. Cambridge University Press, Cambridge

RoTAP (in press) Review of Transboundary Air Pollution. Acidification, eutrophication, ground level ozone and heavy metals in the UK. Department for Environment, Food and Rural Affairs, available at www.rotap.ceh.ac.uk

Strack M, Waddington JM, Rochefort L, Tuittila ES (2006) Response of vegetation and net ecosystem carbon dioxide exchange at different peatland microforms following water table drawdown. J Geophys Res 111:G02006 doi: 10.1029/2005JG000145

Tansley AG (1939) The British islands and their vegetation. Cambridge University Press, London

Taylor JA (1983) The peatlands of Great Britain and Ireland. In: Gore AJP (ed) Mires: swamp, bog, fen and moor, ecosystems of the world. Elsevier, Amsterdam

Thornthwaite CW (1948) An approach toward a rational classification of climate. Geogr Rev 38:55-94

Thornthwaite CW, Mather JR (1955) The water balance. Publ Climatol 8:1-104

Walmsley CA, Smithers RJ, Berry PM, Harley M, Stevenson MJ, Catchpole R (2007) MONARCH: modeling natural resource response to climate change-a synthesis for biodiversity conversation. UKCIP, Oxford

Wieder RK, Vitt DH (2006) Boreal peatland ecosystems. Springer, Berlin

Willmott CJ, Feddema JJ (1992) A more rational climatic moisture index. Prof Geogr 44:84-88

Zuur AF, Ieno EN, Walker NJ, Saveliev AA, Smith GM (2009) Mixed effect models and extensions in ecology with R. Springer, New York

Proofs received from author(s): December 6, 2010 